Joseph C. Miller Memorial Lecture Series

eds. Abdelkader Al Ghouz, Jeannine Bischoff, Sarah Dusend

\title{
Enrique Martino
}

How to Create a Labour Market in Colonial Situations: Spanish Guinea, Southern Cameroon and Northern Gabon, 1890s-1940s 
How to Create a Labour Market in Colonial Situations: Spanish Guinea, Southern Cameroon and Northern Gabon, 1890s-1940s 


\section{Joseph C. Miller Memorial Lecture Series}

eds. Abdelkader Al Ghouz, Jeannine Bischoff, Sarah Dusend

\section{Volume 11}

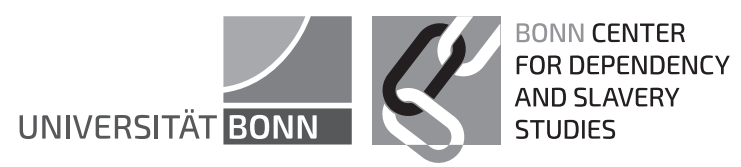




\section{Enrique Martino}

\section{How to Create a Labour Market in Colonial Situations: Spanish Guinea, Southern Cameroon and Northern Gabon, 1890s-1940s}

\footnotetext{
ebv 
Bibliographic information published by the Deutsche Nationalbibliothek

The Deutsche Nationalbibliothek lists this publication in the Deutsche

Nationalbibliografie; detailed bibliographic data are available in the Internet at http://dnb.d-nb.de

Gefördert durch die Deutsche Forschungsgemeinschaft (DFG) im Rahmen der Exzellenzstrategie des Bundes und der Länder Exzellenzcluster Bonn Center for Dependency and Slavery Studies (BCDSS) EXC 2036/1-2020, Projektnummer: 390683433
All rights reserved. No part of this book may be reproduced in any form or by any electronic or mechanical means, including information storage and retrieval systems, without written permission from the publisher or author, except in the case of a reviewer, who may quote brief passages embodied in critical articles or in a review.

Funded by the Deutsche

Forschungsgemeinschaft (DFG, German

Research Foundation) under Germany's

Excellence Strategy - Cluster of Excellence

Bonn Center for Dependency and Slavery

Studies (BCDSS) EXC 2036/1-2020, Project No.: 390683433

\section{(C) $(1) \Theta$}

This work is licensed under the Creative Commons Attribution-NonCommercial-NoDerivatives 4.0 (BY-NC-ND) which means that the text may be used for non-commercial purposes, provided credit is given to the author. For details go to http://creativecommons.org/licenses/by-nc-nd/4.0/

To create an adaptation, translation, or derivative of the original work and for commercial use, further permission is required and can be obtained by contacting post@ebverlag.de

Creative Commons license terms for re-use do not apply to any content

(such as graphs, figures, photos, excerpts, etc.) not original to the Open Access publication and further permission may be required from the rights holder. The obligation to research and clear permission lies solely with the party re-using the material.

This book is available for free download in the Open Access section of the publishers' website. (https://doi.org/10.53179/9783868934045).

A print version is available for a fee from the publisher.

The page numbers in the print and in the online version are identical.

(C) EB-Verlag Dr. Brandt

Berlin, 2021

Coverdesign: (C) Rainer Kuhl, Berlin

ISBN 978-3-86893-390-1 (Print)

ISBN 978-3-86893-404-5 (Open Access)

DOI 10.53179/9783868934045 
Wherever seen it has been an object of intense curiosity, to all persons who think. Yet the question of its modus operandi is still undetermined. Nothing has been written on this topic which can be considered as decisive - and accordingly we find everywhere men of mechanical genius, of great general acuteness, and discriminative understanding, who make no scruple in pronouncing the Automaton a pure machine, unconnected with human agency in its movements, and consequently, beyond all comparison, the most astonishing of the inventions of mankind. And such it would undoubtedly be, were they right in their supposition.

Edgar Allan Poe, Maelzel's Chess-Player

One of the long-standing strengths and recent original contributions of African historiography to the thematics of global economic and labour history has been the focus on regions and periods where a labour market failed to take off, or was simply supplanted by coercive state-mandated tributary schemes of forced labour. Colonial states either prepared such schemes for the benefit of their own public works or for a small number of colonial employers, or alternatively permitted state-like monopoly and concessionary companies and their subsidiaries to do likewise. This preemptive and impatient relapse to a non-commercial and often permanent and veiled mode of sourcing labour through state directives and imperial regulations, such as labour taxes and draconian anti-vagrancy laws, lasted throughout the entire colonial period. ${ }^{1}$ Viewing the structure of colonization in this way has the analytical and methodological effect of bringing

1 Babacar Fall, "Le travail forcé en Afrique occidentale française (1900-1946)," Civilisations: Revue Internationale d'Athropologie et de Sciences Humaines 41 (1993): 329-336; Frederick Cooper, Decolonization and African Society: The Labor Question in French and British Africa (Cambridge: Cambridge University Press, 1996). See also Benedetta Rossi, "Dependence, Unfreedom and Slavery in Africa: Towards an Integrated Analysis," Africa 86, 3 (2016): 571-590; Zachary K. Guthrie, Bound for Work: Labor, Mobility, and Colonial Rule in Central Mozambique, 1940-1965 (Charlottesville: University of Virginia Press 2018); Opolot Okia, Labor in Colonial Kenya after the Forced Labor Convention, 1930-1963 (London: Palgrave, 2019); Julia Seibert, In die Globale Wirtschaft gezwungen: Arbeit und kolonialer Kapitalismus im Kongo (1885-1960) (Frankfurt: Campus Verlag, 2016); Romain Tiquet, Travail forcé et mobilisation de la main-d'œuvre au Sénégal: années 1920-1960 (Paris: Presses universitaires de Rennes, 2019); and the spree of recent journal articles by Alexander Kaese. 
into focus blunt designs and terrors, with responsible agents arranged hierarchically. This simplified foundation of the history of imperialism has made it difficult to approach the expansion and transformation of political economy in African societies and to follow the intricate colonial economic interventions and parameters, such as currency regimes and types of labour contracts, which underpinned the transformation of the productive and reproductive basis of colonized societies.

The longer history of labour market economics, as a section of political economy and a theoretically revived economic history, has never created useful starting points in African history, because its modelling capabilities always came from the "final stage" of an enclosed and perpetual given, a pool of workers competing but each having a range of options to hire themselves to different employers to earn a necessary income. In these frameworks, the reverse scenarios congregated as varieties of "unfree" labour defined according to the absence of these criteria. These assumptions led political economists to reject the need to detect the uneven and fragmented historical emergence of labour markets, because there was little sense of how conditions dominated by these absences could lead to its appearance. It is this well-known axiom of "free labour" in conjunction with a second, more theoretical, note to define the essence of wage labour according to the regular pay-out schedule after completing defined tasks, which made the labour theory of value work: that is the logical conceptual circuit of valorization where all the parts are already set up and functioning without any other relations of dependence or coercion than those which result from the "nature" of the market. And so, the creation of the labour market simply became an extension and expansion of the existing market mechanism to labour. Marx insisted upon these axioms, following what he called a "bourgeoise" mindset: "The question why this free labourer confronts him in the market, has no interest for the owner of money, who regards the labour-market as a branch of the general market for commodities. And for the present it interests us just as little. We cling to the fact theoretically, as he does practically." Marx's eventual historical critique of political economy at the end of Capital was to endlessly underline the centuries of creeping dispossession that ended up in a total market 
dependency of labourers, and to mock the assumptions that there is a "natural basis" for the production of "on the one side owners of money or commodities, and on the other men possessing nothing but their own labour-power", or in contemporary speak of economic history which has all but taken over African Economic History, the factor endowments of capital and labour.

For Marx, labour too acquired the simple and universal status of a commodity in the distinctive sociohistorical simplification of the capitalist division of labour. In what he calls the "historical stamp" or character of labour in the "colonial system", there was of course open recourse to violent state power, where "the concentrated and organised force of society" deployed itself as an "economic power" to "hasten hot-house fashion" the "transition" of "the feudal mode of production into the capitalist mode". Marx leaves it to the very end of the final chapter of Capital, "The Modern Theory of Colonisation", to say what he considered the distinctive colonial character of labour markets to be. Here it was "otherwise", where explicit plans to overcome labour shortages needed to be elaborately developed, and involved compressed and directed attempts "to effect the manufacture of wage-workers". Here "pure monetary relations" were substituted with techniques "supplied by feudal law" that forced or transported or tied down a new labouring class. ${ }^{2}$ Marx's state-centric "theory of colonization" and "primitive accumulation" was an analytical move that transplanted the categories of a rigid or fragmenting "feudalism" into the colonies of the industrial era, with "feudal" in this context usually meaning simply "not liberal", in its association with constricted, artificial and unnatural hierarchies, rather than being an explicit temporalization of the pre-modern stages of capital. The extensions of the imperial state's violent arm to the colonies, where it engages primarily in predation and tribute-collection, have a long history of being reinvigorated conceptually through African history

2 Karl Marx, Capital: A Critique of Political Economy (London: Lawrence and Wishart, 1974), 120, 751-753, 767. For a representative selection of the current tendencies in African Economic History see the special issue edited by Gareth Austin and Stephen Broadberry, "The Renaissance of African Economic History," in Economic History Review 67, 4 (2014). 
and anthropology. ${ }^{3}$ The idea in this piece is to find a complimentary conceptual contour of the overwhelmingly financial and mercantile agents of colonization who created the labour market. Because it is these agents who, as Engels noticed in his supplementary contributions to Capital Volume III, drove the new "colonisation. Today this is purely a subsidiary of the stock exchange, in whose interests the European powers divided Africa a few years ago". 4

However, rather than following the concessionary combines or the monopoly capital that was the primary entity of the classical early twentieth literature on imperialism and its revival in the 1970s, I propose that the key agents to follow in pursuit of this methodological and conceptual alternative are those emissaries and mediators who at a very local level actually managed to establish new colonial relations, and who were often labour recruiters or otherwise concerned with the recruitment and mobilization of a new labour force. Residing in what seemed to be a separate and uncontrollable new underground, producing, or taking advantage of the commercial turbulence brought on by phases of colonial expansion, they were always morally and even economically placed outside of the new colonial order of ideal colonizers (administrators, limited liability companies, missionaries, etc.) and a shifting imagery of the colonized (traditional rulers, peasant villages, assimilating elites, etc.). Recruiters were associated with vectors of disease as well as exacerbators of internal tensions and dysphoria in what Georges Balandier called the "colonial situation". This analysis of "social dislocation" in states of permanent "crisis" is a special vantage point from which to produce an "accurate and fairly comprehensive investigation", he notes. One needs then to simply follow these "new social groupings

3 Samir Amin, "Les effets structurels de l'intégration internationale des économies précapitalistes: une étude théorique du mécanisme qui a engendré les économies dites sous-développées" (PhD Thesis, Université de Paris, 1957); Samir Amin and Catherine Coquery-Vidrovitch, Histoire économique du Congo, 1880-1968: du Congo français à l'Union douanière et économique d'Afrique centrale (Paris: Anthropos, 1969); PierrePhilippe Rey, Colonialisme, néo-colonialisme et transition au capitalisme; exemple de la Comilog au Congo-Brazzaville (Paris: F. Maspero, 1971).

4 Karl Marx, Frederick Engels: Collected Works, Volume 37 (London: Lawrence \& Wishart, 1975), 897. 
resulting from the dislocation of traditional groupings, the appearance of social classes, the nature and role of the proletariat, etc.", and the specific internal and dynamic cleavages along the way. "To these collective circumstances we have given the name colonial situation", but this "colonial situation becomes greatly modified, and at a rapid pace. This fact requires that the situation be studied in an historical manner, that the dates be specified." I agree here too, that is why this text attempts a fine-grained empirical reconstructing of the stepwise unfolding of a colonial labour market, from beginning to end. This attention to "circumstance" is of a conceptual order, so that one can "grasp, in a global sense, the transformations occurring among a colonial people under the influence and actions of the colonial power." 5

The complex dynamics of the price-formation of the commodity "labour" cannot be captured by axioms of game-theoretical bargaining power or stable power asymmetries, nor of course as a naturally arising correct number which approximate the "substance" of value. Adopting such vocabulary impedes the full tracing of historically emergent labour markets because it conceptually creates shadows, "imperfect", "distorted", an "extra-exploitative" "extra-economics". It was entirely historical actors that created the horizon in which new labour would be priced. All the steps and costs imposed by brokerage, and its financial elements, such as commissions and arbitrage, and the advances resulting in peonage and the volatile calculation of returns, heighten the commodified character of labour and compose a market in the properly mercantile sense of the term.

A sustained focus on such recruiters provides for what Jairus Banaji has called an "inquiry" into the formation of a labour market, into "the forms in which employers recruited labour" as distinct from the realms of both the general tendencies of long-term availability and localized labour control at sites of production. ${ }^{6}$ The recruiters' sole area of opera-

5 Georges Balandier, "The Colonial Situation: A Theoretical Approach," in Social Change: The Colonial Situation, ed. Immanuel Wallerstein (New York: John Wiley \& Sons, 1966[1951]), 34-61, 60.

6 Jairus Banaji, Agrarian Change in Late Antiquity: Gold, Labour, and Aristocratic Dominance (Oxford: Oxford University Press, 2007), 197. The latter, he says, are "the methods of control which they used to regulate either the long-term supply of labour or the 
tion was the "field" - to constantly bring in batches of new recruits. A detailed analysis of how a buyer of labour power is put in contact with its possessor, via a market, that is money, along with the carrier and messenger of that promise to pay, reveals a stark contrast to the slave trade or state-organized forced-labour schemes. Recruiters operated non-violently by way of persuasive and distorted communication, and immanently with money in the form of gifts and advance payments. Recruiters had of necessity to know and plug in directly into the internal concerns and social positions of potential recruits, and the large, usually matrimonial economies that bound them to their community, which would collectively absorb massive amounts of monetary media. The recruiter was thus a financial and cultural agent, rather than a political agent, or one who otherwise belonged to colonial state power or corporate management.

In classical schemata or implicit timelines of African history the regressions and excesses of these recruiters often figure as a mere temporal and structural gap, lodged in the failing or progressing "transition" from either slavery or an early state-enforced labour levy to the free labour of market compulsion. ${ }^{7}$ Even in the most empirical and straightforward accounts of a particular constellation of labour mobility, those who realized the demand and furnished the supply of workers became invisible; or worse, became shrouded in rumour, propaganda, and even in the mysticism of an amoral archetype. In histories of colonial labour regimes, even ones that partially focus on recruiters, recruiters have

day-to-day performance of jobs" and was the realm of the literate administrative figures. Whereas to examine recruitment "we simply cannot use the agricultural writers (or the jurists) as a substitute for the sort of 'labour enquiry' which the ancient world either failed to produce or never transmitted to us."

7 Giovanni Arrighi, "Labour Supplies in Historical Perspective: A Study of the Proletarianization of the African Peasantry in Rhodesia," Journal of Development Studies 6, 3 (1970): 197-234; Alan Jeeves and Jonathan Crush, eds., White Farms, Black Labor: The State and Agrarian Change in Southern Africa, 1910-50 (Portsmouth: Heinemann, 1997). There are of course various exceptions such as the most careful pieces of South African labour history's golden age, the book length manuscripts of Charles Van Onselen, Patrick Harries, Alan Jeeves and Jonathan Crush, that always included one or two extensive chapters on the long travails of the recruitment process itself which ferried many migrant labourers from all over southern Africa to the mining centres particularly around Johannesburg. 
appeared as relatively simple, callous but hazy agents who nevertheless somehow imposed, manipulated and reordered the values of local societies to successfully extract labour from them.

The labour recruiters of the colonial period have never been a focus of much sustained interest or systematic concern, in contrast to their equivalents in the pre-colonial period, the slave traders. The intricate networks of the slave trade have always been a central interest, especially in pre-colonial African economic history and the sometimes-protracted period of ending the internal slave trade that continued well into the first decades of colonial rule. The wide window into the original African composition of coastal and regional trading confederacies, as well as specific diasporas and strategic territorial aristocracies which were mercantile rather than ethical communities, as well as the volatile and waning fortunes of specialized middlemen who opened other commodity markets, has been one of the great achievements of African social and economic history. ${ }^{8}$ While the continuities between the slave traders of the precolonial period and their new commercial intermediary activity in the produce trades, the so-called transition to "legitimate" trade, have been amply examined, the new type of intermediaries involved in the formation of the colonial labour market have been very much overlooked. This may be because, in general, labour markets based on colonial contracts were not that significant in African colonial economies in comparison to local or state arrangements based on kin or kin-like social networks, and of course labour tributes or sanctions. The specific techniques and conditions required to mobilize the commodity "labour" in an imperial economy that outlawed slavery remain unclarified, portrayed chaotically through analogies to slavery or the alien imposition of statist forced

8 Gilles Sautter, De l'Atlantique au flueve Congo (Paris: Mouton, 1966); David Northrup, Trade without Rulers: Pre-Colonial Economic Development in South-Eastern Nigeria (Oxford: Clarendon Press, 1978); Paul E. Lovejoy, Transformations in Slavery: A History of Slavery in Africa (Cambridge: Cambridge University Press, 2011); Adiele E. Afigbo, The Abolition of the Slave Trade in Southeastern Nigeria, 1885-1950 (Rochester: University Rochester Press, 2006); Suzanne Miers and Igor Kopytoff, eds., Slavery in Africa: Historical and Anthropological Perspectives (Madison: University of Wisconsin Press, 1979), 3-78; Suzanne Miers and Richard Roberts, eds., The End of Slavery in Africa (Madison: University of Wisconsin Press, 1988); Suzanne Miers and Martin A. Klein, eds., Slavery and Colonial Rule in Africa (London: Routledge, 1999). 
labour, and they thereby carry over many assumptions of the asymmetrical type of power relations that were assumed to continue or be simply interrupted in emerging labour markets.

Where a broker or intermediary figure was included in the study of colonial-era African migrations, the frames of ethnicity and kinship have come to guide and predominate the research of the last few decades. I consider this trend a theoretical impasse, a non-confrontation with money and alienation, and a way to bypass the many structural contradictions that arise when looking at the specific category of relationships between workers and colonial society that have little to do with "embeddedness" and everything to do with highly commercialized exchange. The most interesting aspect about recruiters, is that they do of course not appear as purified market agents devoid of culture or local networks, but as an internal transformation of the Afro-European repertoire of exchange practices with many precursors in the commercial precolonial period and the slave trade. In Eric Wolf's chapter on the slave trade he refers to it as "new trade" "engrafted" upon "kin-organized lineage" societies, which became "fused" with long-distance and commercial elites and networks, principally because the debts arising from the domestic economy, such as bridewealth, became denominated and only payable in currencies provided by slave traders, such as cowries, copper and brass. ${ }^{9}$ This is precisely the insight and message of Joseph Miller's Way of Death: Merchant Capitalism and the Angolan Slave Trade: how did externally injected European credit transform African societies from within, so that slave supply routes opened in between the splits of their societies? ${ }^{10}$ Miller, and this is what he is widely admired for among scholars of African history, did this with unprecedented, conceptually

9 Eric Wolf, Europe and the People Without History (Berkeley: University of California Press, 1982), 204. This process has been explored in detail for the Igbo of Nigeria by G. Ugo Nwokeji, The Slave Trade and Culture in the Bight of Biafra: An African Society in the Atlantic World (New York: Cambridge University Press, 2010).

10 Joseph C. Miller, Way of Death: Merchant Capitalism and the Angolan Slave Trade, 1740 1830 (Madison: University of Wisconsin Press, 1988); Steven Feierman, "African Histories and the Dissolution of World History," in Africa and the Disciplines: The Contributions of Research in Africa to the Social Sciences and Humanities, eds. Robert Bates and Valentin Y. Mudimbe (Chicago: University of Chicago Press, 1993), 167-212. 
guided reconstructive detail, keeping track of what changed hands and what information and misinformation was channelled while these merchants were reordering as many territories as they could.

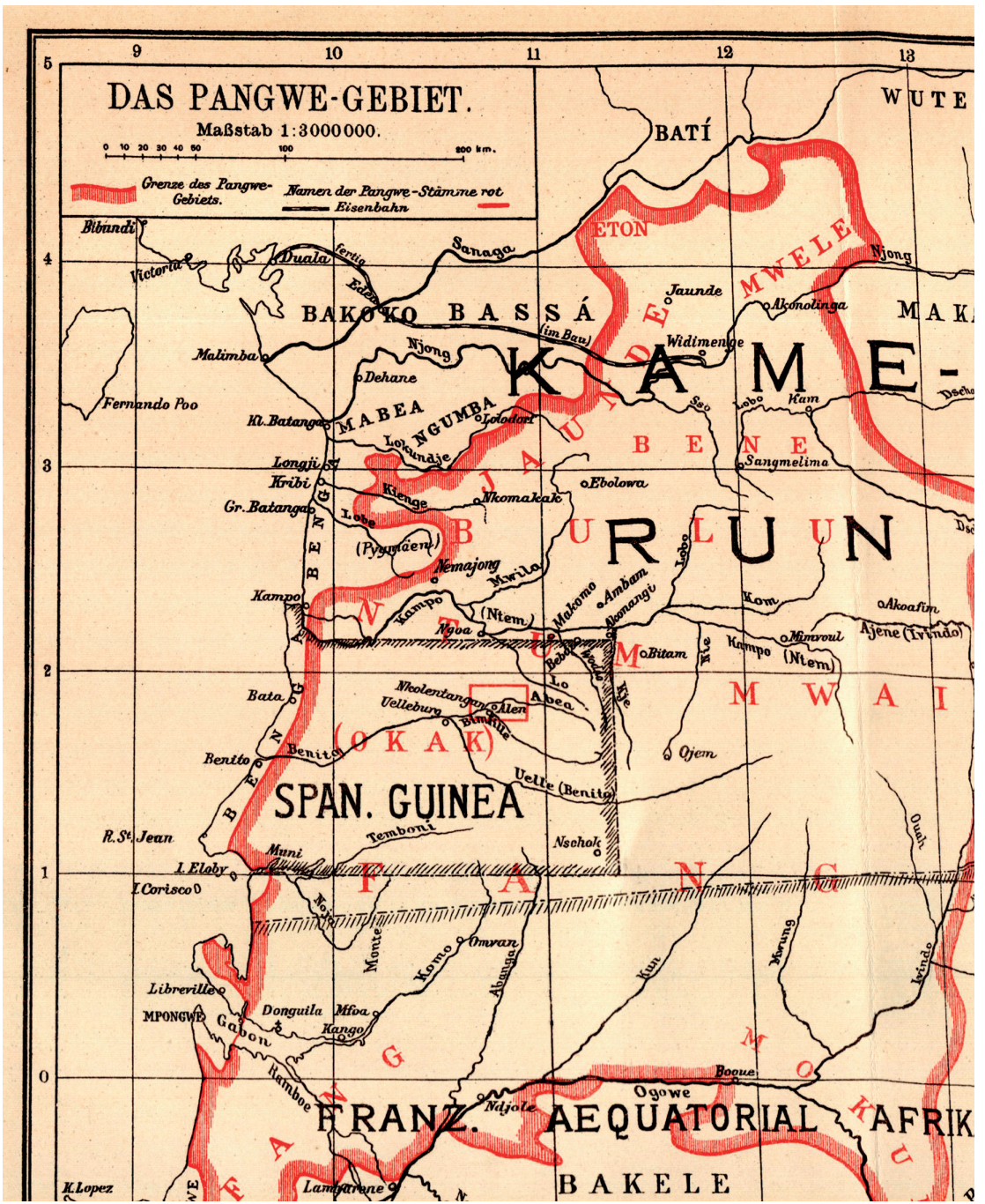

Figure 1: Map of Fang groups around 1910 (Tessmann, 1913). 


\section{Spanish Guinea: Reclutadores and braceros}

These new labour recruiters spread out and reached many more places than early colonial administrators or the previous generation of slave traders, to which they were often retroactively compared. Indeed, colonial-era recruiters seemed to work most effectively in remoter areas beyond the strict control of colonial states, whether in "tribal" and highland India and southeast Asia, various islands in Oceania, or in the marginalized semi- or non-peasant societies of Africa and South and Central America. This type of recruiting was a risky venture, because for recruiters who operated before the consolidation of colonial authority, desertion was rife, but the returns were guaranteed by a growing "periphery" of colonial plantation economies buoyed by the tropical commodities boom.

This is the case for continental Equatorial Guinea, the enclave of Río Muni, which is about a quarter of the size of Cuba, or the surface area of Rwanda, Wales, or the Spanish province of Galicia. Río Muni shifted into Spanish hands only after the signing of the 1900 Paris Treaty - a minor addendum to the Berlin Africa conference. This attached its fate to the colonial economy of the emerging plantation island of Fernando Po, which had been under Spanish administration since the mid-nineteenth century. The result was a boom of labour recruitment that swept into both Río Muni and the neighbouring Fang areas of southern Cameroon and northern Gabon during the first half of the twentieth century. I reconstruct the phases, intensities, and, importantly, the recruitment modalities for this entire period, between the 1890s and the 1940s. I conceptualize these shifts around very specific junctures: the piecemeal consolidation of the Spanish imperial state, the sudden change in political regimes and the associated rupture in policies by newly appointed Governors and their Subgobernadores who were in charge of Río Muni, a sudden burst of extreme labour scarcity because of the cutting off of another usually reliable source of labour elsewhere, etc. These conjectural historical conditions were quite volatile and meant that different forms of labour recruitment were constantly superseding each other at various turns. 
Scandalized contemporaries on the ground talked of multiplications and uncontainable contagions, of "veritable slave-traders resurging in the twentieth century, we call them reclutadores". ${ }^{11}$ From across the border of Spanish Guinea French officials spoke of "employers using methods of the slave-trade rather than recrutement". ${ }^{12}$ Historians too have observed, often disconcertingly, what Catherine Coquery-Vidrovitch called the "plague of recruiters", who forged the distant gateways to the mines and railways under construction in Central and Southern Africa, employing methods, as Frederick Cooper notes, "sometimes closer to kidnapping". ${ }^{13}$ However the recruiters they had in mind were not perpetrators of shocking violence, but engaged in a drawn-out, often negotiated and often uncertain range of transactions and representations. The issue was, as a Spanish republican labour officer wrote in 1930 in relation to the sweep of recruiters in Fang areas, that the "guerrilla of reclutadores have hiked up the prices to such exaggerated heights, that we are no longer talking about a compensation for the ordinary costs of recluta but of the PRICE FOR THE SALE OF A MERCHANDISE CALLED 'MAN'."14

In the pre-colonial period, state formations as well as labour markets, including slave labour markets, were peculiarly largely absent in precisely the area of Río Muni and broadly between Duala in Cameroon and Cape Lopez in Gabon. There were few coastal commercial settlements before the nineteenth century, with the large exception being those established by the most influential coastal group, the Benga around the island of Corisco, who shared much, linguistically, and economically, with other estuary aristocracies, such as the Duala of the Wouri, or the Mpongwe in the area around Libreville. The pre-colonial migrations into

11 Angel Yglesias de La Riva, Politica indígena en Guinea (Madrid: Instituto de Estudios Africanos, 1947), 219.

12 Chef de la Subdivision, Ambam to Chef de Circonscription, Ebolowa, 21 September 1931, ANC, APA, 10165/A.

13 Catherine Coquery-Vidrovitch, "The Colonial Economy of the Former French, Belgian and Portuguese Zones," in General History of Africa, Volume VII, Africa Under Colonial Domination 1880-1935, ed. A. Adu Boahen (Paris: UNESCO, 1985), 351-382, 363; Cooper, Decolonization and African Society, 44.

14 Curaduría (Lasierra), 1930, AGA, C-81/07720, L-2. 
this area are very complex, but it is important to note that by the latter half of the nineteenth century the "square" of Río Muni was particularly densely populated by the Fang, a large and well-known group broadly living between the rivers Sanaga in Cameroon and the Ogowe in Gabon. It is also important to note that the effective colonial occupation of Fang territories in the Spanish zone took place only between 1915 and 1927; in the decades prior to this, Río Muni was overrun by the intense sweep of German wild rubber traders. Rubber, and occasionally ivory, was usually collected by the Fang independently after the (foreign but African) "tradeback" agents of German merchants had already advanced "trust" or trade goods in the villages; it was finally carried out in Germanled caravans from dispersed trading outposts or "Unterfactorien" in the interior. The Fang were described as "skilful traders who like to barter with travellers", and the more powerful clans would occasionally themselves bring "rubber and ivory to the coast in caravans to procure guns and powder", cloths and miscellaneous utensils in more favourable proportions at the German dominated factories in Bata. ${ }^{15}$ Practically all of the European merchant trading stations or "factories" were British and German, with several dozen outposts distributed in Bata, which would become the capital of Río Muni, and further south along the short navigable stretches of the rivers Campo, Benito (Wele) and Muni, as well the island of Elobey, where the primary export were trees felled locally near the waterways.

The problem of labour scarcity and its associated recruitment campaigns are the running theme across Spanish Guinea's colonial history. While there were only a few thousand contract workers in the 1890 s,

15 Karl Ritter, Neu-Kamerun, das von Frankreich an Deutschland im abkommen vom 4. november 1911 abgetretene gebiet (Jena: G. Fischer, 1912), 24; Enrique d'Almonte, Someras notas para contribuir a la descripción física, geológica y agrológica de la zona noroeste de la isla de Fernando Poo y de la Guinea continental española (Madrid: Imprenta del Depósito de la Guerra, 1902), 117. See especially the excellent PhD thesis of Tristan Oestermann, "Kautschuk und Arbeit in Kamerun. Soziale Mobilität, Zwang und Militanz unter Deutscher Kolonialherrschaft" (PhD Thesis, Humboldt University of Berlin, 2020), 324-331; Tristan Oestermann and Peter Geschiere, "Coercion or Trade? Multiple SelfRealization during the Rubber Boom in German Kamerun (1899-1913)," in Beyond the Margins: The Political Economy of Life in Modern Africa, ed. Wale Adebanwi (London: James Currey, 2017), 92-114. 
growing to about 6,000 in 1908; by the early 1930s Fernando Po's cacao plantations exported 12,000 tonnes of cacao and employed about 12,000 contract labourers or braceros. ${ }^{16}$ Ibrahim Sundiata in his work on the social history of Equatorial Guinea paid close attention to the first three decades of the twentieth century, when a small percentage of contract workers were brought in by agents of the Liberian state. Planters on Fernando Po were always keener on alternative sources of labour because Liberian braceros were "onerous", principally because the labour treaty with Liberia stipulated expensive imported food rations, such as Spanish rice and stock fish from the North Sea, and because half of their wages were to be paid in pounds sterling. Their labour had become about three times as expensive as that of Spanish subjects or others who could partly be paid in kind and in pesetas. ${ }^{17}$ Spanish and Guinean scholars have focused their attention on the destructive and often short-lived despotic recruitment of the indigenous Bubi of the island, and increasingly of the Fang in Río Muni as well. ${ }^{18}$

The predominance of Fang workers on the island has however also been underestimated in all the literature. Writing in 1931, a journalist on site noted that while "there are some 'monrovias' left, today the entirety of the human resources working on the island are being imported from Río Muni, the immense majority of the braceros on the island's plantations are 'pamues' [Fang]." ${ }^{19}$ By 1935 they had almost all been brought

16 Sebastian Llompart Aulet, Legislación del trabajo de los territorios españoles del Golfo de Guinea (Madrid: Dirección General de Marruecos y Colonias, 1946), 15; Sebastian Llompart Aulet, Anuario estadistico de los territorios españoles del Golfo de Guinea (Madrid: Dirección General de Marruecos y Colonias, 1945), 190-197.

17 Ibrahim Sundiata, From Slaving to Neoslavery: The Bight of Biafra and Fernando Po in the Era of Abolition, 1827-1930 (Wisconsin: University of Wisconsin Press, 1996), 117122, 142; Brothers and Strangers: Black Zion, Black Slavery, 1914-1940 (Durham: Duke University Press, 2004) 88-98, 249-250; also Nnamdi Azikiwe, Liberia in World Politics (Westport: Negro University Press, 1970), 169-211.

18 Gonzal Sanz Casas, "Los finqueros y el uso del trabajo forzado en la agricultura colonial de la isla de Fernando Poo," Arxiu d'Etnografia de Catalunya 3 (1984), 123-136; Dolores García Cantús, "El trabajo forzado bubi en la colonia española de Fernando Poo, 1891-1912," Between Three Continents: Rethinking Equatorial Guinea on the Fortieth Anniversary of its Independence from Spain, Hofstra University, New York, April 2-4 2009.

19 Emilio Carles, Misioneros, negreros y esclavos: notas de un viaje a Fernando Poo (Valencia: Cuadernos de Cultura, 1932), 33. 
by a "body of recruiters, technically clandestine but perfectly known, who replaced the rulers of Liberia, and turned Cameroon and Gabon into their field of operations." ${ }^{20}$ A Francoist official, writing in 1936, calculated that some 15,000 Fang workers had been "recruited in the last seven years, with the commission averaging 400 pesetas, a sum of at least six million pesetas has been paid out in the slaving industry of the reclutadores." 21 This is an underestimation, as already in 1930 some 5,000 bracero contracts were made in Bata, 4,000 of them with the island as their destination. ${ }^{22}$ The growing labour demands of the cacao plantations in Fernando Po as well the rapidly expanding coffee and logging industries in Río Muni in the 1930s, which quickly came to demand up to 6,000 workers a year, were by the mid-1930s met almost entirely by Fang, many from Río Muni whose "adult male population in its totality was being absorbed and submitted to salaried work". ${ }^{23}$

Two of the largest gaps within the social history of Equatorial Guinea are the surprisingly radical but brief Republican period (1931-1936), about which almost nothing has been published; and secondly, the extent of the extremely turbulent period stretching between the Spanish Civil War and World War II (1936-1945). Highly misleading impressions have been made about the early Francoist period, and even of the Republican period, through an older body of academic research that necessarily relied on Francoist-era books as sources, rather than the archives themselves which have only relatively recently been made accessible. The recruiting situation in the first three decades of the twentieth century in Río Muni has been extensively illuminated by Gustau Nerín and

20 GG (Sánchez Guerra) to DGMC (Alvarez-Buylla), 28 December 1935, AGA, C-81/06867, E-5.

21 Antonio Babiloni Navarro, "Los territorios españoles del Golfo de Guinea vistos por un colono al terminar el año 1936, Libro Segundo," 1 January 1937, AGA, C-81/12427.

22 Cámara Bata (del Pozo) to GG (Manresa), 11 August 1931, AGA, C-81/8095, E-17.

23 DGMC (Canovas) to GG (de Sostoa), 4 June 1932, AGA, C-81/08099, E-15, also in C-81/06415, E-2. In the first census of 1932 for the non-coastal districts in Rio Muni where recruitment was carried out, some 90,000 inhabitants lived in 1300 villages. Román Perpiñá Grau, De colonización y economía en la Guinea Española: investigación, sobre el terreno, de la estructura y sistema de colonización en la Guinea Española, con referencia especial a lo económico, precedido de un estudio general de los territorios africanos (Barcelona: Tall. Ibero Americanos, 1945), 101. 
Enrique Okenve, who have filled with archival substance and panorama the more disconnected early outlines offered by Valentin Oyono and Ibrahim Sundiata. Nerín and Okenve focused particularly on the intense state-led push in labour recruitment during the years 1926 to 1929, as this period marks the conscious and definitive irruption of the colonial intrusion in the memories of the older generation of Fang of Río Muni. ${ }^{24}$

In the first part of this text, I rely on their work and harness some new sources to underline the achievements and insights of their research. I will then focus on the radical reversals of the Republican period, including the abolition of corvée labour known as prestación personal and the long-standing system of unregulated labour recruitment known as la recluta, which only fully bloomed under their rule. These transformations unravelled rather quickly even before the Spanish Civil War, due to various ideological and local contradictions. The Francoist takeover of Río Muni accelerated the existing Republican labour reforms along its imploding paths. As can be demonstrated through an extensive consultation of colonial archives, the early Francoist state reintroduced an intensified regime of forced labour, geared for both infrastructure such as road building and military installations, but also for private plantations, as the different modalities of forced labour (tributary, penal, punitive, emergency, etc.) were overtly designed to reinsert the Fang as braceros into what the more technical Spanish officials liked to call colonial capital's campos de explotación - or zones of economic productivity, that is the cacao plantations on Fernando Po, and the coffee plantations and forestry industry in Río Muni.

24 Gustau Nerín, "Y el cabo Nacarino tenía una guitarra... Investigando la conquista del Muni," in Perspectivas antropológicas sobre Guinea Ecuatorial, ed. Juan Aranzadi Martínez and Paz Moreno Feliu (Madrid: UNED, 2013), 189-201; Enrique N. Okenve, "They Never Finished Their Journey: The Territorial Limits of Fang Ethnicity in Equatorial Guinea, 1930-1963," International Journal of African Historical Studies 47, 2 (2014): 259-285; "Colonización, resistencia y transformación de la memoria histórica fang en Guinea Ecuatorial (1900-1948),” Ayer, 109 (2018): 109-35, 116-118. 


\section{Around 1900: Labour Code Predations}

After 1900, Spanish planters were surprised to find "that there now exists on the coast of Africa a small territory that is now totally the property of Spain. There lives a race called the pamues [Fang], who can substitute those workers who come from Sierra Leone and Liberia. Let's take care of that tribe called pamue and bring them to Fernando Poo, before others benefit from their labour at our expense". ${ }^{25}$ For the first three decades of Spanish rule, Río Muni "in the providential design of colonial policy" was thought of as a "zone that should produce brazos ["arms" or workers]; an appendix to the island." 26 The French navy had in the late nineteenth century informally occupied Río Muni and founded Bata, and ruled it as an extension of their colonial territory of Gabon. They formally prohibited foreign recruiting agents to pass through its coast. Nevertheless in 1897 the French district officer in Bata granted Isabel Blanca, a daughter of the King of Bonny in the Niger Delta, a recruiting license, marking the first recorded transfer of workers from Río Muni to Fernando Po for public works and several Blanca-linked cocoa plantations. ${ }^{27}$ In 1900, it seems the French district officer was no longer placing any difficulties to "this contracting of men except for the one hundred francs that until now the French Treasury has been charging for each man that left Bata", according to then Subgobernador of Elobey, José María Ibarra Autrán, who took a special interest in this question.

Spain already effectively occupied the islands in the Río Muni estuary, Corisco and the Elobeys, and in the 1890s the only Spanish trading enterprise in the region, La Compañía Trasatlántica, established several outposts along the estuary which also engaged in "incidental" recruiting, offering to take decommissioned soldiers and factory agents or

25 José Gutiérrez Sobral, "Guinea Española: la crisis de braceros," Revista de Geografía Colonial y Mercantil 2 (1901): 12-15, 14.

26 Curaduría (Romain Ordoño) to GG (Domínguez Manresa), 16 July 1931, AGA, C-81/8125, E-2.

27 Ibrahim Sundiata, Equatorial Guinea: Colonialism, State Terror, and the Search for Stability (Oxford: Westview Press, 1990), 43. On Blanca see Jose Valero y Belenguer, "La Guinea Española: la isla de Fernando Póo," Boletín de la Real Sociedad Geográfica 32 (1892): 144-365, 250. 
trade workers, who were rarely if ever from Río Muni, to the island, but on a minor scale. In 1901 Ibarra would become Governor of the entire Spanish territories. The first generation of Spanish administrators found it difficult to expand this uncoordinated recruiting activity as the coastal towns were not well connected to the island, with the Trasatlántica setting up a regular steamship line only in 1905. In 1901 Ibarra had appointed one "Mr. Chotteau" as the first authorized recruiter who promised much but only managed to send 250 workers in 1901. Chotteau organized the passage to Fernando Po, which lasted about a day on German steamship lines that stopped in Bata. On the southern end of Río Muni, Chotteau would hire small whalers, schooners and sailing boats that were used by the wholesale commercial companies that circulated along the coast and could transport up to forty passengers all the way to the island. He received "one pound sterling for each person that arrived in Santa Isabel", who required no other paperwork or precondition than appearing visibly "healthy". It was very small scale and almost nothing in comparison to what was to come in the next few decades, and for years it did not make a dent in the island's labour demands, as "recruitment has not yet been properly organised." 28

Chotteau had previously been a representative of the now defunct Belgian concessionary company "Benito y Campo" and his main initial outlay consisted in advancing goods to the "emissaries" who recruited for him along the deltas and in the villages of the main river inlets. They were either local factory agents from West Africa, especially Liberia and Nigeria, or from coastal trading intermediary groups such as the Benga and Combe who as the British Consul notes were, "more inclined to become the means of inducing natives from the interior to undertake work, for which [they] receive[] a commission". ${ }^{29}$ They were called ganchos by the Spanish, hooks or runners, and they were only ever unoffi-

28 José Ibarra, "Una expedición al continente en 1901," La Guinea Española, 25 May, 1928; D'Almonte, Someras notas, 110.

29 Great Britain, Spanish Guinea, Historical Section of the Foreign Office, No. 132 (London: H.M. Stationery Office, 1920), 30. The commercial trading elite of the predominantly fishing societies of the Ndowe considered "agriculture to be degrading, but as they are almost the only natives who can read and write, their services are in demand as clerks, commercial travellers or pedlars, in all of which capacities they do well." 
cially involved as sub-recruiters, because they were barred from ascending to the rank of licensed reclutador. As a group of coastal leaders later recalled, this was a point they had tried to make repeatedly: "[W]e are prohibited from reclutar braceros- against this, we are of the opinion that the recluta should be undertaken by the indigenas, this would benefit the Europeans because we have much better relations with the people of the interior than do the Europeans." 30

Since no other licenses were handed out, in effect Chotteau had a monopoly and his Spanish agent in Bata, A. López de la Torre, who also happened to be the nephew of Governor Ibarra, hiked up the prices of his commission in Bata to the point that several groups of planters from Fernando Po complained to the interim Governors when Ibarra was away. By 1905, Spanish planters demanded that the "appointment of recruiting agents" be opened up, with the new criterion that they should be "locally recognised and influential and of well-known morality, and if possible, to possess the language of the natives": this indicated indirectly why they found Ibarra's appointees especially ineffective. ${ }^{31}$ The applications came rushing in when the British authorities successfully embargoed labour emigration to the island in 1903, which they could do effectively because they ramped up surveillance on the British steamers which connected the island to the West African coast. The applicants were initially "representatives and proxies" of specific planters and companies on the island and were quickly granted licenses after simple requests: "I come to you and with the greatest respect I state that the aforementioned farm is short of labourers and as I am unable to procure them locally and on the other hand it has been almost four months since there have been any braceros from Liberia and perhaps longer since there have been any from Bata, I wish to establish a recruiting agency in the Río Muni region."32 The island's planters were "left with our sole continental territory in Rio

30 Jefes de Rio Benito to Gobernador General (Manresa), 4 August 1931, AGA, 81/08028, E-2.

31 Enrique López Perea, Estado actual de los territorios españoles de Guinea (San Fernando: Libreria de José M. Gay, 1905), 14; Gonzal Sanz Casas, "Política colonial y organización del trabajo en la isla de Fernando Poo: 1880-1930" (PhD Thesis, Universidad de Barcelona, 1983), 239.

32 Angel Traval y Roset to Curaduría, 31 January 1905, AGA, C-81/06417. 
Muni. It is turning into a breeding ground from where we can extract indígenas to bring to the island" wrote the Subgobernador based in Bata, who would become Governor himself between 1906 and 1908. It was only under his reign that the planters managed to commence a "reasonable flow" of braceros from Río Muni. ${ }^{33}$

A handful of private recruiting agents were linked to the German and British trading houses in Bata and the Muni Estuary. A small group of large German planters on the island relied on one "M. Kase, Agent for Messr. E.H. Moritz and acting German consul" who was "importing labourers for their own farms and also for the purpose of giving them to other farmers". The John Holt company with its large cacao exporting houses on the island were known to "pay 5 pounds for each 'boy' landed" either for their various cacao plantations on the island or more commonly in order to informally lend or lease these braceros to various smaller African farmers on the island to secure their cocoa at fixed and reduced rates after the harvest. ${ }^{34}$ An employee of the John Holt Company in Elobey, Mr. Creasey, was regularly sending groups of a dozen Fang workers on one year contracts for 20 pesetas a month, for a small commission of 5 pesetas per contract, while his company paid the 20 pesetas per worker to transport them to the island. ${ }^{35}$ In 1906 John Holt himself had written to the Spanish Minister of the Colonies that his new recruiting agents were having difficulties in Elobey, being "fined" 100 pesetas for "each man sent away". He misinterpreted this as a "fine" (no transgression was invoked), so it was effectively a kickback or cut for the government officials. John Holt also proposed to the Spanish minister that his subsidiary factories in Río Muni become the financial channels and guarantors to facilitate the pay-outs for returning braceros. The dif-

33 Luis Ramos Izquierdo y Vivar and Eduardo Navarro y Beltran del Rio, Descripción geográfica y gobierno, administración y colonización de las colonias españolas del golfo de Guinea (Madrid: Impr. de Felipe Peña Cruz, 1912), 260, 257.

34 British Vice Consul, Santa Isabel (Smallbones) to Foreign Office (Grey), London, 30 June, 1913; British Consul General, Monrovia to Foreign Office, London, 15 October 1913, TNA, FO 367/353; Sundiata, From Slaving, 136.

GG (Barrera) to SubGG (Cobian), 21 November 1912, AGA, C-81/07122, E-2; Deborah J. Neill, "Cocoa Capitalism: John Holt \& Co. on Spanish Fernando Pó in the early Twentieth Century", in press, citing Liverpool Record Office, UK, 380 HOL I/9/1 Coast Letter Extracts, Fernando Po letter, 31 August 1906. 
ficulty in repatriating earnings and the deduction of the accrued wages at the end of the contract led to a situation already in 1906 where:

The boys will not go to Fernando Po as they are badly treated there, by which is meant that they are flogged too much and they are not paid the wages which they ought to receive in Fernando Po after their terms of service is ended. When they return to Bata and go to see their family, they are laughed at because they have returned without any money, and the boys report the treatment they have received there, and this is spread all over the country with the consequence that nobody wants to go to the Island again ... I am sure that you will agree with me that the foundation of all successes in this matter is humane treatment, fair wages and reasonable food and accommodation. The thing requires to be arranged along the right lines-without too much detail or red tape, but on sensible lines which will imply freedom on the part of the man who sells his services, and due fulfilment of the employment of the terms of engagement. ${ }^{36}$

These revelations were already well known in Madrid where Alvaro de Zulueta, in his annual report of 1902, wrote that the braceros' rights were "illusory", and the accusations of ill-treatment, non-payment of wages, arbitrary fines, insufficient rations, forced extension of contracts and physical punishments were widespread. The natural scientist Manuel Escalera had also publicly denounced the conditions in more extreme terms as the "wretched preyed upon by philanthropic traffickers" in a talk and publication of the Geographical Society of Madrid. ${ }^{37}$ In 1905, a Spanish recruiter invoked Spanish metropolitan law to try to get back braceros whom he had recruited but who were now working for other employers. In order to secure their release, he cited the Spanish constitution according to which "no Spaniard may be imprisoned except by vir-

36 John Holt, Liverpool, to DGMC (Bosch), 25 July 1906, AGA, C-81/7122, E-6.

37 Secretario General, Santa Isabel, 31 January 1903, AGA, C-81/6949, E-8; Sundiata, From Slaving, 131-139; "Sociedad Geográfica. Conferencia del Sr. D. Manuel M. Escalera," El Imparcial, 9 January, 1902, 2-3. Also cited in Enrique d'Almonte, "Los naturales de la Guinea Española, considerados bajo el aspecto de su condición de Súbditos Españoles," Boletín de la Real Sociedad Geográfica, LII, 4 (1910): 401-437, 409. 
tue of a warrant issued by a competent judge", as "any person arrested or detained without legal formalities, or outside the cases provided for in the Constitution and the law, shall be released at his own request or at the request of any Spaniard." 38 It was clear that Spanish Guinea needed its own labour code specific to its "situation".

In August 1906 the new Gobernador, Ramos-Izquierdo, promulgated the Reglamento del trabajo indígena para los territorios españoles del Golfo de Guinea. This labour code was coeval with labour regulations being set up in Spain, where for example the Labour Inspectorate was only founded in 1903 and focused on specific questions like holidays and child labour. The reglamento allowed for both "free recruitment" in Río Muni (chapter II "Contratación libre en el continente español") and "official recruitment" (chapter III "Recluta official de braceros, obreros y servidores domésticos en los distritos de Bata y Elobey para Fernando Póo") prompted by the district authorities who were instructed to produce a "reasonable number" of labourers from "each village" - which in reality meant villages near the colonial towns on the coast. The code also effectively expanded the institution of the Curaduría Colonial and the figure of the Curador, equivalent to the Labour Office, which had previously existed only as a contract making and tax collecting agency. The Curador was given the mandate "to promote the civilisation of the indigenous people by encouraging (impulsándole) them to work", and tasked to explicitly "provide" the administration, companies and employers with the "indigenous workers they needed". In all matters of dispute, only the Curador could be the "representative" of braceros. ${ }^{39}$ By 1908, the majority of the 5,600 workers on Fernando Po had been "embarked" in Bata and in the southern district of Elobey around whose estuaries many southern Fang had settled. The Curador announced, certainly prematurely, that the "problema de braceros on this island is now solved" and hoped that

38 Angel Traval y Roset to Curaduría, 31 January 1905, AGA, C-81/06417.

39 Llompart Aulet, Legislación del trabajo, 23-38; original in AGA, C-81/7722, E-1; Jordi Domenec, "Legal Origin, Ideology, Coalition Formation, or Crisis? The emergence of Labor Law in a civil law country, Spain 1880-1936," Labor History 52, 1 (2011): 7193. 
the "good treatment will help continue the already established flow of emigration to this island of braceros from Bata and Elobey". 40

The preamble to an amendment to the labour code from 1909 described the primary mode of recruitment and tried to put an early end to the surge of reclutadores by simply cutting them out and only allowing planters or employers to hire their workers directly. This was "necessary" because "their agents and auxiliaries were contracting braceros for the sole purpose of subsequently transferring them to other employers, and in a way to sell them, which has led to a real trade which is highly harmful to the general interests of agriculture". The preamble added that in this way braceros were thus forced to work for the employers who happened to be the highest bidders and that workers were feeling "deceived", as they would invariably end up in a different plantation and under different conditions than promised, and would subsequently encourage their relatives "not to be recruited themselves so as not to fall victim to similar deception". ${ }^{41}$ While a few amendments were added over the years, the labour code remained virtually intact until 1953, and it is important to note that there is no mention of the word "free", "freedom" and the like in the labour legislation; the sole exception being in 1913, when "freedom" is mentioned in its orthodox meaning, the "freedom to choose" another contract with the same or another employer after the expiration of a first contract. ${ }^{42}$

In 1908 the Governor, a colonel who had spent most of his life as a functionary in Cuba and Puerto Rico, created the Guardia Colonial, amalgamating the "Indigenous Police" with a naval infantry company and the customs guards. Headed by the Spanish Guardia Civil, this ramped-up force of around 400 men, came to quickly supplant mediations that previously had been loosely linked through initiatives of the planters, their agents and the ganchos. Unsurprisingly, there was an immediate upsurge in "official recruitment". A planter wrote in a missionary newspaper that the "salvation of Fernando Poo lies in Bata" and reported that "90 per

40 Curaduría (de la Puente) to GG (Ramos Izquierdo), 27 July 1908, in Ramos Izquierdo, Descripción geográfica, 317.

41 Miranda Junco, Leyes coloniales, 375.

42 Miranda Junco, Leyes coloniales, 396. 
cent of our workers" were coming from Río Muni. By 1914 the number of braceros from Río Muni was still around 3,900, growing to 6,200 in 1916. An increasing portion of workers had been coming again informally from Liberia since 1909 and shot up to around 2,500 in 1915 after the signing of a new labour treaty with the Liberian president. ${ }^{43}$ Overall demand was intensifying, too, because of the reversal of the halt in land concessions between 1900-1909. By 1914, the surface area under cultivation had almost doubled. In 1911, there were around 90 large planters with over 100 hectares who ideally needed to employ around a hundred braceros each. Almost half were African Fernandinos and the other half Spanish, Catalan mainly, while a handful were Portuguese, English, and Germans. $^{44}$

When the Duke of Mecklenburg, Adolf Friedrich, passed through Bata in 1910 and in conversation with the German agent of the Woerman firm there noticed that "the Spaniards seem to use it mainly as a source for obtaining labourers for the Fernando Po plantations, and the methods employed in their capture must be described as a modern slave trade. The sub-governor of Bata receives no official salary, but is paid 70 pesetas, i.e. about 50s [shillings], for every workman he supplies. No further comment is needed!" - "Der kommentar hier ist uberflussig!" reads the sarcastic shock of the original text. ${ }^{45}$ The locals saw it in more vivid but not different terms than this aristocratic passer-by. In 1913, an extraordinary letter written in Bata reached Rodrigo Soriano, a wellknown Republican politician who published it on the front page of his

43 Vicente Barrantes, "En pro de nuestro continente," La Guinea Española, 25 March, 1911; Gonzalo Álvarez Chillida, "Claves de la historia colonial española de la Guinea Ecuatorial," in Guinea Ecuatorial (des)conocida: Lo que sabemos, ignoramos, inventamos y deformamos acerca de su pasado y su presente, ed. Gonzalo Álvarez Chillida and Juan Aranzadi (Madrid: UNED, 2018), 247-411, 296.

44 Jordi Sant i Gisbert, "El comerç de cacau entre l'illa de Bioko i Barcelona: La Unión de Agricultores de la Guinea Española (1880-1941)" (PhD Thesis, Universitat Pompeu Fabra, 2017), 62. On the recruitment of Kru labourers from Liberia and the role of the Fernandinos in the nineteenth century, see Enrique Martino, "Money, Indenture, and Neo-Slavery in the Spanish Gulf of Guinea, 1820s to 1890s," Comparativ 30, 5/6 (2020): 560-580.

45 Adolf Friedrich, From the Congo to the Niger and the Nile: An Account of the German Central African Expedition of 1910-1911, vol. 1, 2 vols. (Philadelphia: J. Winston, 1914), 7. 
radical newspaper Nueva España. I will quote this letter at length, and note that the highly significant ellipses are from the source itself:

Mr. Soriano, here the people of colour have been returned to the days of slavery. Many of the cocoa planters here are cruel tormentors and they are aided, abetted, and protected by the ... the ... the ... the ... (I dare not say his name) [The Subgobernador?], who is the biggest tormentor of them all... and the executioner above all. This evil executioner has the bowels and heart of a tiger. For all the evils he is doing they won't remove him, because he is protected by ... (I dare not say his name either) [Governor Barrera?]. As the planters have been so cruel, people here in the colony do not want to work for these people, who give poco pago, mala comida, y mucho palo [little pay, bad food, and many beatings], so the Governor has made the soldiers force the people of the Muni, Benito, and Bata, with threats, to come to Fernando Poo to hire themselves as braceros; and since it is they who have weapons, no one dares to resist and so they seize the defenceless. If a bracero escapes before boarding the ship, they burn his house down, they cut down his fruit trees and raze his farms to the ground. May God protect those who were not born white. So it appears that God does not hear us, the King [Alfonso XIII] is the one who has sent us a slave trader. ${ }^{46}$

This imagery of the "bowels" of a "tiger" or leopard metamorphizing into the quasi-cannibalistic grew very much out of local imaginaries of predation as theorized by Joseph Tonda for the region. However, as Phillipe Descola has noted elsewhere, and this seems to be the case for the Fang understanding of hunting and predation as well, the "tiger" is of course not simply a metaphor but an image of the distinct type of human relationships that is contrasted with reciprocal exchange and other non-predatory relations. Predation is thus not simply about seizing and incorporating an object with metaphorical claws, but also a matter of asymmetrical and suspicious arrangements that can include "in equal

46 "Cosas del mundo", España Nueva: Diario de la noche, Madrid, 4 April, 1913. Letter signed by "Gracias anticipadas por todas las tribus Bengas, Balengues, Cumbes, Bicos, Maris, Garas, Bujebas, y Pamyes" to Rodrigo Soriano on the 25 February 1913. 
parts, of cunning and seduction, trying to beguile them with misleading words and false promises." 47

In another petition signed by a dozen Fang and other chiefs the authors do not distinguish between private recruiters and state agents tasked with this type of paid conscription, but they do make a conceptual distinction between market and state: "Ever since Spain took possession of these lands, we have had or seen nothing that brings betterment to this colony. That there is a law established in Brussels by international pathways prohibiting the sale of slaves puzzles us Chiefs, because from the moment that braceros from Liberia stopped coming, the Spanish nation has taken up the everyday selling of Spanish subjects, selling us without mercy." The petition was directly addressed to the first new Republican governor just months after the Second Republic had been proclaimed, and explains how the people of Bata were "resentful that the Republic has retained the rulers that perpetrated the injustice of the recent past." The writer of this petition, an educated person from one of the missions, related a varied set of demands close to the heart of the new Republican regime: "[N]o schools have been built to benefit the young, also there is no distinction between the Europeans; whether they are planters or reclutadores they are all governing without respect for the state". ${ }^{48}$ Before we examine the reversals and failed potential of the Republican period, we need to establish what exactly the state came to be in the intervening decades, as it was effectively synonymous with the strategies of the longest running and most assiduous Gobernador of Spanish Guinea, Angel Barrera.

47 Joseph Tonda, Le souverain moderne: le corps du pouvoir en Afrique centrale (Congo, Gabon) (Paris: Karthala, 2005); Philippe Descola, "Beyond Nature and Culture: Forms of Attachment," HAU: Journal of Ethnographic Theory 2, 1 (2012): 447-471, 460. 


\section{1910-1925: Barrera and the Fang of Río Muni}

Barrera is best known for almost single-handedly organizing the occupation of the interior of Río Muni. He took on the mantle of the very keen head of the colonial office in Madrid, Eduardo Bosch (1901-1910), who established a whole range of foundational and enduring administrative statutes, including for the Guardia Colonial and the Curaduría. Bosch evidently never found someone reliable on the ground, as in the first decade of Spanish rule in Río Muni there were ten different governors. They had mostly been navy officials who got expelled from Cuba in 1898 and left Guinea as soon as they had another promotion, or a disagreement with Bosch. Barrera was the Gobernador between 1910 and 1925, having come from a colonial career in the Philippines in the 1890s. He had spent five months as a prisoner of war of the Americans and shared the widespread view that the revolt in the Philippines was due to the despotic control of the Spanish over the local population. He feared that similar unrest would be repeated in Río Muni. He could be surprisingly tactful and resourceful as well as spectacularly cruel and egomaniac. To commemorate the signing of the labour treaty with Liberia for the supply of braceros in 1914, he immediately arranged for a large bust of himself to be raised in the central square of Santa Isabel. His disinterested new superiors at the colonial office in Madrid often did not even respond to, let alone finance, or authorize, most of his many plans for the colony, as during this period they were engaged in a very intense war in Morocco. In addition, many in Madrid fully expected that Río Muni would eventually be taken over by their large and more powerful neighbours in Central Africa, as the French and German governments repeatedly claimed or offered to purchase the neglected territory from Spain. ${ }^{49}$

An important element of the wider history of this period is that in 1916, 35,000 German and Cameroonian refugees arrived in Spanish Guinea. These were the entire German colonial administration of Kamerun and their loyalist soldiers and the latters' families, when they

49 Nerín, La última selva, 40-48; Álvarez Chillida, "Claves de la historia colonial," 292301. 
finally fled from the last battles with the French and turned up in Bata en masse. About 15,000 of them ended up staying on Fernando Po in 1916-1918, financed by Germany; but Barrera dedicated himself almost full-time to the necessary logistics, provisions, and diplomatic consequences. He arranged for the onward journey of the 1,200 Germans and senior Cameroonians to Madrid; and while much of the remaining contingent went back to Cameroon in 1918, about a third remained on the island, which had a population of around 15,000 people, so this influx helped of course alleviate the labour question. The vast majority were "Ewondo" (Beti) from the area around Yaoundé, of the so-called Beti-Bulu-Fang group, whom the Germans called "Pangwe", the French "Pahouin" and the Spanish "Pamues". ${ }^{50}$

During his long and impactful reign, Barrera organized complex expeditions lasting several months along meandering paths that took them increasingly closer to the formal borders with Gabon and Cameroon. These "tours" took up almost one tenth of the colonial budget, or around 10,000 pesetas, and occurred almost annually, intensifying after WWI. They depended on a loose affiliation of at least several hundred guides, porters, soldiers, and their families. They were hosted by dozens of the larger Fang villages, who were given a constant stream of gifts and symbolic promotions, complete with miniature Spanish flags, which made it appear to Spain that sovereignty was being exercised over a still militarily unoccupied territory. Indeed, a large portion of the colonial budget was specifically dedicated to such diplomatic gifts, which were rather an implicit toll to permit the convoy to pass through. Nevertheless, the realities of violent encroachment soon became apparent. The head porters, who were mostly Bujebas from the coast, would "explain" to Fang village representatives in a mix of Fang and Pidgin that "they have accepted the new invaders. The Bujebas would warn them that whoever resisted was executed". ${ }^{51}$ In Barrera's own words this would

50 Miquel Vilaró i Güell, La internación de la Schutztruppe: la Guinea Española en la Gran Guerra (Madrid: Letras de Autor, 2018); Pierre Alexandre and Jacques Binet, Le groupe dit Pahouin: (Fang - Boulou - Beti) (Paris: Presses universitaires de France, 1958).

51 Carlos Fleitas Alonso, Guinea: episodios de la vida colonial (Madrid: Agencia Española de Cooperación Internacional, 1989), 48. 
involve the regular public executions of "prestigious chiefs", and "ruining of entire villages" by setting fire to them, a spectacle of extreme violence to imprint their presence on the memories of the colonized so they "would understand that nobody attacks Spain's sovereignty and disobeys its representatives." A particularly notorious case was the execution of the Fang leader Mbogo Nsogo of the Samangon clan, who had effectively surrounded Bata and charged heavy tolls to anyone, including Barrera, who wanted to venture inland. According to the informants of Enrique Okenve, Mbogo Nsogo was "beheaded in public in the district capital" shortly after World War I; in the collective consciousness this marks the beginning of defeat: "after this, everybody was overwhelmed with fear and they resigned themselves." The unyielding Barrera was given the Fang nickname "Akok da lara beki (stone that strikes iron)" - "a plunging, crushing rock that one cannot fight", who descends "like a piece of fate". 52

While Barrera allowed forced recruitment in the narrow corridor where the Guardia Colonial had established a loose string of firm outposts, he personally pursued his preferred method of campaigning in the non-conquered areas of Río Muni "based on persuasion”. His expeditions were quite effective at increasing the number of young Fang recruited as braceros. It was an aspect of what Barrera paradoxically called the peaceful "policy of attraction" which he counterpoised to the directly coercive modes of recruitment by the captains of the Guardia Colonial, who were continuously meting out contracts to the island as punishments, a process he did not interfere with. ${ }^{53}$ Up until Barrera left the colony in 1924, the sole planters' lobby on the island implored him to organize "the complete and rational occupation of the 26,000 square kilometres of Guinea Continental, with which we will undoubtedly achieve a solu-

52 GG (Barrera) to DGMC, 30 June 1912, AGA, C-81/06276; cited in Enrique N. Okenve, "Equatorial Guinea 1927-1979: A New African Tradition" (PhD Thesis, SOAS, 2007), 116,110 . The last quote on the origin of power and punishment is of course from Friedrich Nietzsche, The Genealogy of Morals (New York: Random House, 1967), 82. 1924, AGA C-81/06444, Exp. 1; Okenve, Equatorial Guinea, 108-112; Nerín, La última selva, 26-34, 50-55; Nerín, Corisco y el estuario del Muni, 188-193. 
tion, even if only partially, of the problema bracero." ${ }^{54}$ He certainly could not but ignore the extravagant demands of the planters to intensify this coercive modality, because his regime did not have the budget or military resources.

In 1912, Barrera had already pushed through sweeping new amendments to the labour code in order to lower the cost of "free recruitment" that had been rising due to competition among planters. This in turn escalated the commissions and the distribution of gift-advances to the labourers themselves. The regulations also tried to ensure the voluntary nature of the contracts, by requiring the "signing" to happen in front of an official of the Curaduría in Bata. Once signed, the one-, two- or threeyear contracts were of course irrevocable. They could only be annulled if both contracting parties agreed to it. He also devised a new wage pay-out system obligating planters to deposit and pay out half of the monthly salaries at the Curaduría, with the other half being paid out in bulk at the end of the contractual period, so that braceros would not leave empty-handed if planters went bankrupt. Under Barrera's reforms many planters started to be fined and bankrupted for non-payment of wages and physical abuse of workers. Barrera thought that by enforcing the new legislation more braceros could be "attracted", if good news of improving conditions could spread with the return of contract workers on their way back to their villages.

In his expeditions he was almost always accompanied by dozens of returning braceros who hitched a ride back home, in order to bypass the more onerous "tolls" of the powerful clans. He enlisted them as "propaganda" agents, making the "ones who had returned happy explain to the others what they had done and what they had earned, how the wage allowed them to later acquire clothes and the goods to pay the women's dote [bridewealth], to buy tools for their agricultural work, to bring other ideas into the forest than the ones they had, making them change little by little, without their realizing it". ${ }^{55}$ The history of the monetarization of Fang bridewealth and the adoption of colonial currencies to

54 Sanz Casas, "Política colonial," 224.

55 GG (Barrera) to Presidente del Directorio Militar, Ministerio del Estado, 14 December 1924, AGA C-81/06444, E-1. 
settle the debts of affinal and matrimonial alliances is complicated, and it was only after the completion of this process in the late 1920s that labour recruitment reached the tens of thousands, enveloping much if not most of the Fang population of Río Muni, Gabon and Cameroon. ${ }^{56}$ It is only necessary to point out here that certain European imported goods that braceros could purchase with or received instead of wages (gunpowder, salt, pots, pans, hats, cloth and shirts, machetes and axes and the like) could already substitute traditional iron currencies and goats in the preliminary and supplementary components of bridewealth payments from the early twentieth century onwards, if, that is, they were categorized as what the Fang called akum or wealth. ${ }^{57}$

Barrera's officers in the Guardia Colonial saw their mission as a partly protective one, and in many instances their destacamentos or outposts were being actively solicited and welcomed by specific Fang clans and villages in Río Muni, who were said to be engaged in drawn-out conflicts relating to unpaid or pending bridewealth payments, and initially considered the Guardia as a possible defence. For the Fang who found themselves living on a new colonial border, the ever more persistent presence of the Guardia also served as protection against the more intrusive and labour-capturing Germans in the period before World War I, and against the French tirailleur soldiers after 1916. When German Neu-Kamerun had come to encircle Río Muni in 1911 after the Morocco-Congo Treaty, the Germans launched the first road-building scheme in the region, from Ebolowa via Ambam and Bitam to Libreville, closely surrounding Río Muni. The possibility of flight to the Spanish side of the border proved a great relief. After 1916, "constant incursions by French soldiers" started, who crossed an imaginary und undefined line "into our [Spanish] territory" to "steal chickens and goats, break Spanish flags", and "recruit by brute force". Very often, when Fang - who had strategically settled on the straight-edged border, a boundary that ideally marked the limit to

56 Enrique Martino, "Nsoa ('dote'), dinero, deuda y peonaje: cómo el parentesco fang tejió y destejió la economia colonial de la Guinea Española," Éndoxa: Series Filosóficas 37 (2016): 337-61; Leon Mba, "Essai de droit coutumier Pahouin," Bulletin de La Société des Recherches Congolaises 25, June (1938): 5-53; Georges Balandier, "Actualité du problème de la dot en Afrique noire," Le Monde Non Chrétien, 21 (1952): 36-47. 
colonial soldiers but to no one else - fled into Spanish territory, French soldiers "pursued and took them and forced them to work on roads" that were being expanded in northern Gabon. Barrera spent much of his time furiously protesting these incursions and sending his delegates to visit the affected villages. ${ }^{58}$ The Spanish, by contrast, had still not built any roads except in and around Bata.

In the early 1920s the origin of the braceros was correlated only with the onward march and intensity of activity around the outposts along the border and detachments of an occupying force in Río Muni. ${ }^{59}$ The lieutenant responsible for the northern border was called Julian Áyala, who was posted in the only area of the interior where the Spanish had a consolidating presence. Operating out of Mikomeseng, he would visit and inspect villages in the area. If anyone refused to surrender their arms or obey the arbitrarily set labour tributes enshrined in the labour code, he would first "confiscate their weapons", and then "send them to jail for 6 months and then to a two-year contract on Fernando Poo, so that they return more civilized". 60 Under "the regime of Barrera" as "pacification" and the enforcement of the tributary labour tax called prestación for and around the many smaller military outposts unfolded, the punishment for those "fleeing from prestación" was to be "sent to work as a bracero on the island for a minimum of two years". In 1925, a chief near the north-eastern border confronted a Spanish Guardia Colonial and told him "that in this village I don't want to see any guards and we won't work on any bridges or roads." The chief and his supporters "were detained and sent to work on the plantation in Fernando Poo". 61 By 1925 some 3,200 Fang braceros were divided among 59 employers on the island - about as many as there were Liberians. ${ }^{62}$

58 SubGG to GG (Barrera), 16 June 1922; GG (Barrera) to Gouverneur AEF, Brazzaville, 20 June 1922; AGA, C-81/7193, E-1.

59 Valentin Oyono Sa Abegue, "L'évolution des structures productives et sociales de l'économie de la Guinée Equatoriale 1858-1968" (PhD Thesis, Université de Lyon II, 1985), 480.

60 Teniente Comandante (Ayala), Mikomeseng, to GG (Barrera), 1 October 1922, AGA, C-81/7193, E-2.

61 Nerín, La última selva, 114, 219; citing AGA, C-81/7198; C-81/7633, E-11.

62 Sundiata, From Slaving, 123. 
The Fang were what anthropologists used to call a leaderless or an "egalitarian" society. As Balandier observed, they had "never exhibited the slightest trace of feudalism." Their entire social structure had "preserved them from any excessive concentration of power", successfully warding off despotism exacted through coercion and terrorized consent. Here Balandier is talking about the "southern Fang", that is the Fang-Fang, Ntumu and Okak of Río Muni and Gabon, whose political hierarchies were much more "flat" than those of the closely related Beti and Ewondo groups of Cameroon. ${ }^{63}$ As Günther Tessmann repeatedly emphasized in his 1913 ethnographic monograph Die Pangwe, the Fang chief or nkukuma "does not exercise any real power, especially in the south where he can seldom reign over his stubborn and wilful subjects". ${ }^{64}$ Pre-colonial Fang chiefs came in various political, rhetorical, military and economic stripes, but the nkukuma, big men or literally "wealthy man", came to predominate. Nkukuma were those who grew rich - that is, instituted an unprecedented level of polygamy - under a regime of value conversion during the boom in the salt, ivory, and rubber trades between the 1840s and early 1900s. ${ }^{65}$ Chiefs could not be enlisted as direct collaborators for labour recruitment: when they did, they ceased being "chiefs", since their alignments were now elsewhere. This is expressed in the kinship-based language of alliance in a work song of forced labourers in southern Cameroon addressed to a Beti chief (called Ahanda) who was supervising road building in the 1920s: "Ahanda, will you get a white woman for this? Ahanda, who has told you the whites are your friends? Ahanda, will you marry a white man's daughter?"66

63 Georges Balandier, The Sociology of Black Africa: Social Dynamics in Central Africa (London: Praeger Publishers, 1970), 143. Okenve, Equatorial Guinea, 72-75.

64 Tessmann, Die Pangwe, 208.

65 James Fernandez, Bwiti: An Ethnography of the Religious Imagination in Africa (Princeton: Princeton University Press, 1982), 61-62; Jan Vansina, Paths in the Rainforests: Toward a History of Political Tradition in Equatorial Africa (Wisconsin: University of Wisconsin Press, 1990), 134-5, 234-268; Samuel M. Eno Belinga and Jane Guyer, "Wealth in People as Wealth in Knowledge: Accumulation and Composition in Equatorial Africa," The Journal of African History 36, 1 (1995): 91-120.

66 Nicolas M. N'Nah, Domination coloniale au Gabon: les combattants de la première heure (Paris: L'Harmattan, 1981), 51. 
Fang politics was not marked by any composite and cumulative authority or any sort of centralization, so "conquest" had to operate village by village, as did recruiters. As Meillassoux observed, certainly "colonial troops more often encountered resistance from domestic societies than from kingdoms or empires with a reputation for being powerful" - it was these "domestic" societies based on kinship who continuously rejected the ultimate and final blow "to establish domination over such communities by force". Georges Dupré and Pierre-Philippe Rey observed that the "problem presented to the European traders by the irruption of the unhierarchised Fan along the Gabon coast could be solved only by a colonial conquest" - the imposition of "political order by force" in "order to carry on with trade." 67

When the Spanish turned inland from their string of border outposts, they were repeating the German and French strategy of conquest undertaken in neighbouring Fang areas many years and even decades before, but with a twist: the economic demands of Fernando Po were the ends of almost every intervention. With a twist, and a particular intensity. In 1926, with an extraordinary credit exceeding the entire colonial budget granted by the new heads of the colonial office in Madrid to a new Gobernador, Miguel Núñez de Prado, there were suddenly around 770 members of the Guardia Colonial in Río Muni - 85 Spaniards, with 2 captains, 11 lieutenants, 51 "cabos" and 685 soldiers, mostly from Senegal and Cameroon. While in 1900 the entire German Schutztruppe in Cameroon that had by then effectively conquered a territory the size of Spain, at one of the most militarized peaks of German colonial conquest, comprised "40 German officers, 53 NCOs and 900 African mercenaries," from the Gold Coast and Togoland. ${ }^{68}$ A German general in 1901 who spearheaded this swift conquest, understood "subjection" to be societies that would "voluntarily provide services to the conquer-

67 Claude Meillassoux, Maidens, Meal, and Money: Capitalism and the Domestic Community (Cambridge: Cambridge University Press, 1981), 85; Georges Dupré and PierrePhilippe Rey, "Reflections on the pertinence of a theory of the history of exchange," in The Articulation of Modes of Production, ed. Harold Wolpe (London: Routledge, 1980), 171-208, 199, 202.

68 Nerín, La última selva, 196; Helmuth Stoecker, German Imperialism in Africa: From the Beginnings Until the 2nd World War (London: Hurst, 1986), 79. 
ors", whether it be forced labour on road-works or "wage labour in the colonial economy". ${ }^{69}$ Labour recruitment was expected to happen only if accompanied by political submission, but it did so unreliably and not without the introduction of other factors, like the adoption of new colonial currencies and the potential for spectacular violence. In Cameroon, recruiters only followed in the wake of what Mbeme called the predatory period of German rule that was particularly intense under Putkammer's reign (1895-1907). Not until the establishment of military outposts and patrols could the "commercial agents based in southern Cameroon initiate the enrolling [of] workers through anarchic operations". ${ }^{70}$

\section{1926-1935: State and Market Oscillations}

Gustau Nerín's long-running research and appreciation of the local and archival realities is truly singular, and his account of the persecutions carried out by Julian Ayala, a Captain of the Guardia Colonial, is no surprise. He has shared with his readers the many macabre stories, sometimes surreal, of the atrocities committed by Ayala, the face of mass colonial violence, which everyone in Río Muni over a certain age grew up with. Ayala was essential, the initial backbone of the mass labour recruitment drive built on top of an unprecedented expansion of prestación during the road-building programme under Núñez de Prado (1926-1930). In the autumn months of 1926, some 4,500 braceros and 1,181 accompanying women workers were sent to the island from Río Muni through the direct intervention and for the immediate profit of members of the

69 Albert Wirz, Vom Sklavenhandel zum kolonialen Handel: Wirtschaftsräume und Wirtschaftsformen in Kamerun vor 1914 (Freiburg: Atlantis, 1972), 127.

70 Achille Mbembe, La naissance du maquis dans le Sud-Cameroun, 1920-1960: histoire des usages de la raison en colonie (Paris: Karthala, 1996), 167; For African recruiters see Andreas Eckert, "African Rural Entrepreneurs and Labor in the Cameroon Littoral," The Journal of African History 40, 1 (1999): 109-126, 116. See also Adolf Rüger, "Die Entstehung und Lage der Arbeiterklasse unter dem deutschen Kolonialregime in Kamerun (1895-1905)," in Kamerun unter deutscher Kolonialherrschaft: Studien, ed. Helmuth Stoecker, vol. 1, 2 vols (Berlin: Rütten \& Loening, 1960), 149-242, 190-200. 
Guardia Colonial. ${ }^{71}$ The braceros recruited by the Guardia went only to members of the lobby of Spanish planters, the Cámara Agrícola. Planters with less standing in the lobby, or who did not form part of it, relied on an influx of private reclutadores who started traversing the entirety of Río Muni and beyond.

Ayala quit his functionary status in 1928 and became the exclusive full-time recruiting agent for the Cámara - working partly on commission, he quickly became the highest earner in the colony in the process. Recounting an incident in 1929, Juan Sanjaume, a premier private reclutador, recalls how he approached a corporal of the Guardia Colonial and "asked him for permission to take some of the [prestación road workers], but was refused outright". Sanjaume was near Ebebiyin and there he had a rendezvous with a local schoolteacher called Laureano Moneache, from a coastal group near Bata, whom Sanjaume knew from when they both worked at the Labour Office in Santa Isabel. Moneache "explained the matter for him, because in this region he [Sanjaume] will not manage to recruit anyone, these braceros are all given to Sr. AYALA." Sanjaume "offered the teacher a hundred pesetas for every bracero he would reserve for him, to which said teacher responded that he is an employee of the state, and he can't be devoting himself to these types of dubious things". Sanjaume however did manage to find a fellow Spanish "Public Works engineer who sold them [Fang prestación labourers] to Sanjaume" for a small commission. The operation of the private reclutadores was thus necessarily increasingly extra-territorial, that is they had to go to Gabon and Cameroon, with methods counterposed to the recruitment directly linked to the prestación applied by the Guardia Colonial.

When the dictatorship of Primo de Rivera fell in early 1930, a handful of staffers at the Spanish colonial office abolished prestación and sent various investigators to interview practically the entirety of the colonial population of Río Muni and a handful of local chiefs and teachers about the widely circulating impression that the "recluta de braceros in our colony has become a market, with an 800-peseta price tag for the unit

71 GG (Nùñez de Prado) to DGMC (Jordana), 12 October 1926, AGA, C-81/07646; Nerín, La última selva, 225. 
HUMAN". The express aims of Julian La Sierra - who produced the 500page report titled Información instruida para depurar hechos denunciados en la Direccion General de Marruecos y Colonias sobre la recluta de braceros - was to determine the extent of the involvement and corruption of members of the Guardia Colonial and the administration. La Sierra was shocked by his own conclusion that "pretty much everyone has been involved", "absolutely everyone has been gripped by this fever". He says he was only "half-joking" when he wrote "that la recluta has become a deranged desire, as it has even come to take over the activities of the missionaries of the Sagrado Corazon de Maria". Even the head of the Claretian mission, Leoncio Fernandez, at Nkue, the largest missionary outpost in the interior, admitted: "[W]e only do campaigning for our own plantations, employing no material or spiritual violence whatsoever" or otherwise "pass them on in a state of total liberty to Casa Mallo", a very prominent planter who did much to support the missions' activities. After "perusing" the tome of depositions and testimonies he gathered, La Sierra states that it is "clear" that "this activity is not monopolized by anyone. Exactly the opposite is the case, la recluta is in the hands of approximately a hundred trotamundos", globetrotters, and at least five hundred ganchos or African runners, who "freely traverse the forest only with the baggage of their know-how and contraptions". La Sierra supposed that the ultimate cause was the "greed for easy profits which has been awakened in all and been enlivened by the lavish and boastful premiums paid out by the demand side", i.e. the planters. ${ }^{72}$

When in the first half of the 1930s the Republican regime abolished prestación, and simultaneously the French in Gabon and Cameroon started accelerating their own regime of prestation for public works, Río Muni came to play the same unique role as a type of "safe haven" as it had earlier in the century. As Gilles Sautter noted, the "fear" of a mass "flight to Spanish Guinea" became an "obsession" of the French district

72 AGA, C-81/6418, E-1: Julian LaSierra "Información instruida para depurar hechos denunciados en la Direccion General de Marruecos y Colonias sobre la recluta de braceros. Agosto-Septiembre 1930". A second, shorter follow-up investigation was conducted in July 1931 by Ricardo Ferrer Barbero dealing more exclusively with Ayala and the Guardia Colonial, AGA, C-81/6418, E-2: "Información encaminada a averiguar la forma en que se efectua la recluta de braceros en la Guinea española." 
administrators across the border, who had been assigned the task of keeping their declining population intact and of building roads. A travelling senior French colonial officer, Le Testu, writing during the first years of the comparatively peaceful early Republican rule of Río Muni, considered the enclave to have become a space "where censuses, native taxation, levies and native justice are unknown", where it seemed to be still possible to live "in complete freedom" - "freedom" in its etymological sense of not being subject to foreign rule or despotism. Le Testu's insistence seemed to emerge from the fear and fantasy of this mass escape of subjects. Emigration, he though, fulfilled the "most ardent desire" of the Fang which was "to avoid any kind of authority, whether native or foreign". ${ }^{73}$

In response, in the early 1930s the French started "expanding their surveillance of clandestine recruiters who have installed themselves on our border" - recruiters "of doubtful moral character, who are well known amongst all the chiefs of the Ambam subdivision" in southern Cameroon. The "Spaniards come all the way to Ebolowa and Yaounde [and] pay for the costs of acquiring a passport for those desiring to emigrate", the laissez passers. ${ }^{74}$ By 1935 Ayala had long joined the ranks of the private reclutadores and again came out on top. He was known as the "primary and the most active propagandist" of the "most active" band of reclutadores. The band was made up of "old associates" from the Guardia Colonial such as "the mulatre Bingua [Bengoa]", as well as a "notorious" German palm oil planter near Bata, "Kreshmann", but Ayala himself was singled out as the most "humourless and villainous character - he's an absolutely shameless recruiter". ${ }^{75}$ Another Spanish recruiter from a different band was known to have crossed into Cameroon "looking to

73 Gilles Sautter, "Les paysans noirs du Gabon septentrional. Essai sur le peuplement et l'habitat au Woleu-Ntem," Cahiers d'Outre-Mer 14 (1951): 119-59, 129; ANG, Gouvernement, Oyem, Rapports periodiques: "G. Le Testu, Rapport sur la tournée effectuée en Guinée Espagnole de 26 juin au 7 juillet 1933", cited also in Balandier, The Sociology, 169-173.

74 Chef de la Subdivision, Ambam to Chef de Circonscription, Ebolowa, 21 September 1931, ANC, APA 10165/A.

75 Chef de la Subdivision, Ambam to Chef de Circonscription, Ebolowa, 1 August 1934, ANC, APA 10165/A. 
recruit about 350 people, so he set up a campaign all along the border with an entire team of rabatteurs" - touts or stalkers, the African ganchos. However, possibly because of his lack of reputation or because he was being outcompeted on the advances he could offer, he "didn't manage to recruit anyone [and] lost his onerous baits, the pricey lures, the advances deposited with his agents". ${ }^{76}$

Maurice Mveng noted that already in the late 1920s over 4,000 Cameroonians had left for Fernando Po across the land border to Río Muni. In 1930 the circunscripción of Kribi in south-western Cameroon was said to have lost a quarter of its population. Exact figures are hard to come by, as the "movement was clandestine", but Sautter observes that "all force and all deception aside, the [lower prices] in the Spanish territories exerted a certain attraction on a people for whom the system of bridewealth absorbs large quantity of goods and money". Goods were indeed $75 \%$ cheaper in Bata than in Gabon, and the total sum of advances, wages and rations under Spanish employers was almost twice as high as the wages for qualified administrative staff, such as clerks and translators, in Cameroon. ${ }^{77}$ Armed with these price asymmetries that emerged and were maintained by the border itself, including commercial borders such as the French-imposed tariffs on certain import goods such as alcohol, ganchos had a relatively successful time becoming mediums and messengers.

The crossing of borders was risky; arrested ganchos were handed down severe penalties and even long prison terms by the French authorities. Jacob Kuaku Nartery was a carpenter from Accra working in the timber town of Kogo along the Muni estuary, in direct line of sight of Gabon. In early 1931, at his workshop, he was "approached and offered a 350 peseta commission" by two Spanish "planters without a recruiting license", who also provided him with a "small boat and many bottles of Cognac." In less than a month Nartery managed to send over 50

76 Chef de la Subdivision, Ambam to Chef de Circonscription, Ebolowa, 11 February 1935, ANC, APA 10165/C.

77 Maurice Mveng, "Note sur emigration des Camerounais ä Fernando Po entre les deux guerres mondiales," Abbia 23 (1969): 34-43, 37; Nerín, La última selva, 229; Sautter, "Les paysans," 129, 145. 
recruited braceros with the wage advances paid in pesetas, but of course these could only be spent in the factories in Río Muni. While he sent ahead the recruited labourers with another gancho, Nartery only made it back to Kogo with some delay, after "slipping past the prison guards" of a French jail in Libreville, where he found himself after being sentenced to ten years in prison for "illegal recruitment". Nartery did not let this detain him, he had already "arranged" with another " 65 braceros to meet him" in a location near the border that had been "agreed to beforehand". In Río Muni these new braceros went with the two Spanish planters, who had instigated the operation, to an official in Rio Benito who stamped the contracts for their own farms and for other employers. ${ }^{78}$

The amendment to the labour code from 1909 allowing only employers to recruit was evidently not applied or enforced. That decree sought to intervene in what was already the primary mode of recruitment, and to put an end to the recruiters who "sold" on contracted workers to the highest bidders. ${ }^{79}$ The rising prices generated by this "speculation" of braceros is the moment employers started collectively denouncing recruiters as alien to colonial interests, because they ate away at larger and larger shares of their productive profits. However, in economic terms speculation emerges automatically in any accelerating market because it is just an anticipation of the moment of exchange. This calculated expectation of alterations of demands that would lead employers to offer diverging and higher prices to reclutadores would thus lead other recruiter-brokers to pursue the same opportunity for "arbitrage" to thus harmonize inflating prices. This "arbitrage" becomes the source of profit, replacing the fixed and direct pre-arranged commissions of commissioned agents. Once enough recruiters were operating without a tied allegiance or planters were free to pass on their excess of already recruited braceros, the goal became not the organizational growth of a specific employer, but only the speculative expectation of an augmented final profit. This is why Weber, in his study of financial markets, says

78 Teniente Comandante, Guardia Colonial, Kogo, to GG (Manresa), 2 August 1931; Gouvernement General de l'Afrique Equatoriale Francaise (Antoneti), Brazzaville, to GG (de Sostoa), 21 July 1932 AGA, C-81/8126, E-1.

Miranda Junco, Leyes coloniales, 375. 
no one can prevent a "self-employed broker" from "speculating" as they easily "shade over into" "speculation", meaning the marking up of prices in a scarcity through this very mechanism, or "speculators in the most genuine sense of that word" ${ }^{80}$ This arbitrage-based commission paid by the island's planters rose from about 50 pesetas in the early 1920s to up to 800 in the early 1930s. As a reclutador was overheard saying in a beach bar in Bata in 1930, "there is no labour scarcity, the only thing one needs if one wants braceros are pesetas." 81 Considering that the average income for Europeans in Bata was 500 pesetas a month, that "margin of profit actively sustain[ed] a large army of intermediaries, direct and indirect, who by all possible means made sure they directed the workers to the island." 82

To the new Republican labour officer, it was "the fact that the recruiters have jacked up the price of cacao production which lies behind the uproar". "When all this talk of immorality is heard, what is alluded to tacitly is only this high price". ${ }^{83}$ From the Republican colonial office in Madrid the recruiters were viewed as "slave traders, they are completely demoralizing the place, by both mistreating the indigenas and exploiting the employers. They are all undesirables, who in addition dedicate themselves to contraband, the sale of alcohol, and all sorts of disgraceful trades." ${ }^{84}$ Summing up the first few years of Republican rule, the radical journalist Francisco Madrid wrote a private letter to a new Governor in 1933: "[T]he slave trade and the sale of alcohol are the order of the day. Nothing has changed, the only thing that has improved is the organization of public health". ${ }^{85}$ Francisco Madrid, who had the ear of several Republican governors, had made the public plea to reorganize the labour

80 Max Weber, "Commerce on the Stock and Commodity Exchanges," Theory and Society 29, 3 (2000): 339-71, 359.

81 Herbert Bauer, 21 August 1930, 'Manifestación', in AGA, C-81/06418, E-1; Leonardo Rubio, 21 August 1930, 'Manifestación', in AGA, C-81/06418, E-1.

82 Cámara Bata (del Pozo) to GG (Manresa), 11 August 1931, AGA, C-81/8095, E-17.

83 Curaduría (Romain Ordoño) to GG (Domínguez Manresa), 16 July 1931, AGA, C-81/8125, E-2.

84 DGMC (Forns Quadra), 13 June 1934, AMAE, R887, E-52. [AMAE, Archivo General del Ministerio de Asuntos Exteriores, closed since 2013 and transferred to AGA; new call number unassigned].

Francisco Madrid to GG (Lluesma), 7 November 1933, AGA, C-81/06467, E- 19. 
market on new principles, an abstractly extended state: "Not until the state cuts off the feeding frenzy of these reclutadores aventureros ... can we say that the REPUBLIC - the spirit of justice - has landed in the colony. The state has to supplant the reclutador for him to perish." The state "should uproot these delinquents, put them in jail, and even if they have turned themselves into finqueros [planters] or even if he has set up a little shed, a factoria, from which to distribute alcohol to the indígenas, to try to gather them and send them to the island, under awful working conditions, they should be expelled from the colony and the role of reclutador should be taken over by the state", a state to be "manned only by the most virtuous of people." Francisco Madrid did not imagine who would come to occupy and operate the administrative apparatus next. ${ }^{86}$

The balance between colonial political economy and morality, and between planters, their profits, and the public treasury which subsisted on export tariffs, was drawn out most succinctly by the most radical of all Republican Curadores, Pedro Agustin Ordoñez Gonzalez (1930-1933). He had been denounced by the planters for having "joked" in front of the braceros in his labour office that he would like to see "the whites doing plantation work" and the braceros "holding the whip", 87 but in the most comprehensive report on the matter, co-authored with his deputy, he simply concluded that: "In essence, the immorality of la recluta is not technically the act of la recluta as such, or even in its techniques and procedures." If "there should be any evils, then let these be established as necessities by the economist" and any subsequent necessary legal measures "could then ratified by the state." Ordoñez briefly became Governor after the acting governor Sostoa was assassinated in 1932; he was appointed Subgobernador in May 1933. Certainly, his meticulous letters and calls for reform transformed the colonial landscape, though with

86 Francisco Madrid, La Guinea incógnita: vergüenza y escándalo colonial (Madrid: Editorial España, 1933), 120-129, 109.

87 AGA C-81/7720, E-25: "Expediente incoada en virtud de escrito dirigido a este Gobierno General por la Cámara Agricola Oficial de Fernando Poo, referente a la actuacion de la CURADURÍA COLONIAL en materia de disciplina de los braceros en las fincas. Enero 1932". 
many false starts as there were five different governors between 1933 and $1936 .^{88}$

\section{1935: Free Labour and the Collapse of La Recluta}

La recluta seemed unstoppable because, as various Republican functionaries confirmed, "almost the entirety of the whites here in Guinea have been involved in la recluta"; "our colony has become a mere colony of exploitation and a feudal territory for the white race, where the business and the fortunes of the few have been allowed to rule supreme". 89 Nevertheless, by 1935 the Republicans managed to put a radical stop to this system through a series of suspensions and attempts to imagine a new order altogether. The most significant change of this period was the halting of the forced labour of prestación in 1930. It was reintroduced in 1933, but in a comparatively milder form as a programme for the "maintenance of the road-network": it was remunerated, limited to no more than six days a year, and restricted to the road network within a five-kilometre perimeter of the drafted labourer's own village. ${ }^{90}$

In 1933 the Republicans had invested all their efforts and put their faith in a large-scale state-to-state organized indentured labour treaty with the French Cameroons, to reroute and "eliminate the reclutadores altogether," hoping that matching the island's labour needs with an external source of labour regulated with fixed prices "would lead to the automatic disappearance of this social class, that stain, the reclutador, that has been an insurmountable obstacle to our colonization." The agreement was signed, but the condition that Spain had to first return

88 Curaduría (Romain Ordoño) to GG (Domínguez Manresa), 16 July 1931, AGA, C-81/8125, E-2.

89 Ángel Miguel Pozanco, Guinea mártir: narraciones, notas y comentarios de un condenado a muerte (Barcelona: Colección Actualidad, 1937), 86; Curaduría (Romain Ordoño) to GG (Domínguez Manresa), 16 July 1931, AGA, C-81/8125, E-2.

90 GG (de Sostoa) to Consejo de Ministros, Madrid, 12 August 1932, AGA, C-81/08179, E-5: "Reglamento de conservación de vias de comunicacion a cargo de colindantes"; AGA, C-81/12426, E-3: "Reglamento de la prestación personal en la zona continental de la Guinea Española. 1933” 
and deport the several thousand illegally emigrated French Cameroonian subjects was never fulfilled, and so by 1935 this alternative source faded away. ${ }^{91}$ Nevertheless, the Republicans had followed up on the other conditions of the treaty and introduced a series of reforms that crushed the unregulated recruiters. The commissions and advances were eliminated by means of extraordinary fines of thousands of pesetas, and ganchos were being jailed in Spanish Guinea. ${ }^{92}$

For a brief period of about a year, starting in the spring of 1935, the Republican Gobernador Ángel Manzaneque set out to change the "status quo in our colony, which has always been run under a total state of exception". Manzaneque disbanded the recruiters and replaced them with labour exchanges, bolsas de trabajo, in government buildings, which anyone was free to approach. He reported back to his superiors: "I have had to battle hard for this new labour regime; everyone was opposed to it; they saw in it the death of la recluta, and of misrule, but I have managed to come out triumphant. They now recognize the need to live within the law". ${ }^{93}$ He took much credit for an idea that had been proposed at the grassroots for years, especially by those economic interests outside the monopolistic planter lobby. A petition of indigenous Bubi farmers on Fernando Po already put forward this "idea" in 1931 to the first Republican Gobernador, namely that "braceros should be freely allowed to search out diverse patrons, and be paid on a daily basis", "without contracts", because, as they claimed and testified to, for those "now entering into a contract, for the braceros, means bad treatment, and many deaths from being overworked and beaten by the masters, all for 20 pesetas a month?". The small Bubi and Fernandino farmers had from early on opposed the contract system represented by the Curaduría, because they could not officially hire labour at all, as they were not "emancipado" colonial subjects who had rights that were largely equivalent to Europeans. Only settlers and a small number of mostly Fernadino elites with this certified status could make contracts with workers: “[S]

91 GG (Lluesma) to DGMC (Álvarez-Buylla), 18 September 1933, AGA, C-81/6867, E-5.

93 GG (Manzaneque) to DGMC (Alvarez-Buylla), 24 May 1935, AGA, C-81/06867, E-7. 
o that the labour question will apply to all equally, we need to make the CURADURIA disappear."94

A type of circumscribed free labour, monthly contracts with no advances or rations, was given the green light in Río Muni. The large logging concessions were being heavily exploited in the Republican period, and the colonial coffee plantations that had been planted along the BataMikomeseng Road built in the late 1920s, were already yielding their first harvests. Indeed, their labour needs were considerable, up to 10,000 braceros, about half the total number needed in Fernando Po. The ability of planters and logging companies in Río Muni to hire labourers within their "home districts, and who would not need to leave their homes and families" seemed like a straightforward option, but for various reasons this did not work in practice. ${ }^{95}$ Nevertheless the employers' lobby of Río Muni was naively optimistic about the natural attraction of a transparent market without necessary mediation. In 1932 their president wrote the Gobernador that migration would occur naturally with a hike in wages: "[W]e repeat, the problem of reaching out and liaising with brazos is actually not that difficult, we believe that what is lacking in this world is good, remunerated work in all latitudes." "Whether" the "braceros come from Río Muni" or "China, Liberia or neighbouring Portuguese, French or English colonies, it shouldn't be difficult to get them to come" if "good working conditions" and "decent pay" were made to exist. ${ }^{96}$

The bolsas de trabajo were housed within the eight headquarters of the Administraciones Territoriales, the local districts of Río Muni, where

94 Jefes Bubis to GG (Manresa), 28 August 1931, AGA, C-81/08028, E-1: "Proposiciones de los hijos del Pais. Los Bubis". Even for those who could hire labour, their main issue with the Curaduría was that the requirement of a deposit of $50 \%$ of the braceros' monthly wages was "impossible for us". Undercapitalized small farmers would only earn pesetas after a harvest or otherwise be dependent on usurious creditors to cover these upfront costs. From 1938 on braceros could only be contracted by those with a "canonical marriage" certificate. In the late 1950s, the so-called "cooperativas indígenas del campo de Fernando Poo" organized the Bubi farmers by villages and localities, and through these they could hire braceros. The 30 cooperatives only hired about 169 braceros in the late 1950s, see Patronato de Indígenas de los Territorios Españoles del Golfo de Guinea, "Datos para su historia y antecedentes y memoria del 1954", BNE, D/16263. 
small advances of up to 100 pesetas could be handed over, depending on the length of the agreed contract, and employers could be firmly chosen. Almost nobody signed up for Fernando Po, and the planters there started to panic. They were "feeling profoundly the lack of brazos." "Once the braceros finish their contracts, practically all of them return to their country, and no new recruits are taking their place". ${ }^{97}$ The many thousands of Fang braceros who had returned from Fernando Po by 1936 had been turning to more lucrative coffee farming in their own villages. This late Republican experiment was soon withdrawn, as the colonial office let it be known that "free labour [was] to be established, always and only if and when it does not cause a loss to our Treasury". 98 The bolsas that might have directed people to the plantations on Fernando Po lay abandoned: as a planter in Río Muni explained, the "bolsas cannot furnish an intense yield, unless they are surrounded by a number of elements that serve as links between the [employers] and the unemployed indígenas - those who can be turned into braceros". ${ }^{99}$ The links needed to connect the braceros had been disarticulated.

Two top-level consultant-reformers sent from the colonial office in Madrid foresaw that the "completely ineffective system" of bolsas was "bound to degenerate into a more or less manifest recluta with even more vices taking hold because la recluta is being pushed underground, plunging us back into our recent history". ${ }^{100}$ Yet the Republicans were resolute in their suppression of la recluta. As the last Republican labour officer says in his final report on the matter, "To allow la recluta again is so monstrously immoral and counter-productive for our colonizing action that we shouldn't consider it even for one second."101 This report was stored away in a box when the Francoists took over Bata in October

\footnotetext{
97 Cámara to GG (de Mendívil), 1 April 1937, AGA, C-81/8129, E-2.

98 DGMC (Nombela), 9 May 1935, AGA, C-81/08126, E-1: “Orden autorizando proroga contratos".

99 Cámara Bata to SubGG (Calzada), 4 April 1938, AGA, C-81/08126, E-1: "Proyecto de ordenación de gestiones para captación y aplicación de braceros destinado a las firmas patronales de la Guinea Continental".

100 Eugenio Arizcun Carrera and José María Martínez y de Pons, "Memoria sobre los territorios españoles del Golfo de Guinea," 1935, 96, BNE, AFR/13541.

101 Curaduría (Guixeres) to GG (Sánchez Guerra), 24 April 1936, AGA, C-81/09010, E-1: "Informe sobre el problema de braceros".
} 
1936, sinking a steamer and destroying the seat of the Subgobierno where the remaining Republican administration had tried to regroup after the quick fall of Santa Isabel in September 1936. The new rulers reversed the reforms by simply effectively permitting recruiters again and leaving the bolsas in their abandoned state. Republican loyalists, amongst whom where many of the labour recruiters, all fled to Cameroon via Ebebiyin - aided in their passage of exile by the many connections they had made during the recently eclipsed recruiting days. ${ }^{102}$

\section{1936-1945: The Early Francoist Doubling}

It is a testament to the strange efficacy of Francoist propaganda, and the inaccessibility of its colonial archive until this century, that even the academic research of the highest quality published in the late twentieth century left a very misleading impression of the Francoist colonial period. Even in his otherwise masterful From Slaving to Neoslavery, Ibrahim Sundiata hastily wrote that "Spain adhered to the Forced Labor Convention of 1930 but forced labor (prestación personal) was not abolished until the late thirties." Spanish diplomats in Geneva had indeed signed the International Labour Organization's convention of 1930, but the Francoist regime almost instantly annulled it, and the new militaristic regime not only reintroduced but intensified various modalities of forced labour, both in the metropole and the colonies. ${ }^{103}$ In his memoirs, Francisco Ela writes that the beginning of Francoist rule marked "the harshest [mas duros] years of colonialism". He explains how "prestación was not limited to state or public works but extended to the labour needs of private companies" and he adds, probably as a sign of how the disused bolsas of the Republicans became merged into new, shorter-term requisitioned labour for private employers, a description of "something similar" to prestación that was "known by the name 'Bolsa', which consisted in sending work-

102 Pozanco, Guinea mártir, 126-128, 197.

103 Sundiata, From Slaving, 144; Fernando Mendiola, "The role of unfree labour in capitalist development: Spain and its Empire, nineteenth to the twenty-first centuries," International Review of Social History 61, S24 (2016): 187-211. 
ers for free during the harvest months to the big coffee plantations in the area of Bata."104 The head of the Claretian missionaries predicted in 1950 that "our pamues [Fang] will never forget the destruction and ruins that accompanied our actions; the only palliative that can weaken this pain and hardship is that which flows from the law of charity and the forgiveness that missionaries preach". 105

Sundiata's international prominence led to a series of profound mischaracterization in the African history literature that had always had to look at Río Muni from the outside, if at all. Crawford Young cursorily noted: "Spanish domination was weakly structured and belatedly imposed, and requires no further attention." Young leaves his readers with a lifeless image of a "skeletal colonial administration", that strikes anyone familiar with the archive as inconceivable and contradictory: "In Río Muni exercise of hegemony only slightly extended beyond the range of timber concessions. In Río Muni, Spanish administration was minimal, sufficient only to assure secure conditions for small lumbering enterprises." 106 This impression is even more surprising because the official and critical propaganda of prominent contemporaries, both inside and outside the colony, was the opposite. Before his trip to Río Muni in 1962, the American Ambassador in Gabon was "told some weeks earlier by President Léon Mba that conditions in Río Muni for the Africans were worse than in the Portuguese colonies, that there was forced labor and that Africans were whipped and bastinadoed." 107 Spanish Guinea probably had the highest concentration of European colonial officers and their armed forces per square kilometre in the whole of Africa. A similar statistic can be claimed for the concentration of roads which was seven times higher than the average in neighbouring colonies. In 1945, tiny Río Muni had a 1,000-kilometre road network, navigable all year round.

104 Francisco Ela, Guinea: los ultimos años (Santa Cruz de Tenerife: Centro de la Cultura Popular Canaria, 1983), 11, 13.

105 Leonicio Fernández, Memorias de un viejo colonial y misionero sobre la Guinea Continental Española (Madrid: Revista El Misionero, 1950), 50.

106 Crawford Young, The African Colonial State in Comparative Perspective (New Haven: Yale University Press, 1997), 153.

107 US Department of State, American Embassy, Libreville, 5 August 1962, AGA, C-81/08690, E-7: “Trip of Ambassador Darlington to Río Muni”. 
Some three hundred kilometres of these had been constructed in the late 1920s, but the bulk were built in the early Francoist period, and all were being continuously repaired and added to - with bridges, asphalting, drainage ditches, requiring small mountains of gravel created through prestación personal. In contrast to neighbouring colonies, in Río Muni even the local and remote courts were presided over by Spanish district administrators - who were always officers of the Guardia Colonial, and who had various immediate underlings who were, peculiarly, almost all Spaniards too. ${ }^{108}$

What led the early Francoists to impose these unusual densities of officialdom and oversized public works? The overdetermining answer can be found in the attempts to prolong the recruitment of Fang labour for the plantation and logging lobbies. The Francoist colonial state in Spanish Guinea, like the Spanish colonial regimes which preceded them, was fundamentally structured by the ongoing question of the problema bracero or the scarcity of labour - a "permanent crisis" of imminent "collapse". ${ }^{109}$ In the early Francoist period this lead to a series of repetitive and intensifying "solutions" for the problema that was "always on top" "in CAPITAL LETTERS, like this," "la cuestion eterna", "it has turned my head into a coconut. I have sent you the acts of the meeting by steamer. As you will see they are very extensive."110

The Francoist loyalists who found themselves taking over the administration of the colony initiated new experiments mixing old and new regimes of labour mobilization. Eugenio Touchard, a captain of the Guardia Colonial during the road-building phase in the late 1920s, briefly assumed the position of Subgobernador of Río Muni in 1937 and in the large district of Bata he immediately reassumed the mandate of "shoving people into the plantations by force." Even amongst the cadre

108 Gonzalo Álvarez Chillida and Gustau Nerín, "Guinea Ecuatorial: el legado de la colonización española," Ayer 109 (2018); 13-32; Yglesias, Politica indígena, 220-224, 237-364; Pélissier, Los territorios españoles, 70. 168 kilometres were asphalted and 847 were laterite.

109 DGMC (Díaz de Villegas), 16 August 1952, AGA, C-81/12373, E-392.

110 SubGG (Calzada) to GG (Fontán), 1 October 1938; SubGG (Cabrera) to GG (Fontán), 18 August 1939; SubGG (Calzada) to GG (Fontán), 1 February 1939; SubGG (Cabrera) to GG (Fontán), 25 April 1940, AGA, C-81/08195, E-2. 
of new Francoist appointees, Touchard was known and mocked for his brutal tendencies and particularly crude racism. Other administrative officers saw the civil war years as an opportunity to allow reclutadores to roam free again, and they were given on-the-spot "licenses" to "travel through all the districts". While the "reclutadores have sent out ganchos to all the villages, these ganchos however have only provided for a very slight relief" of the labour scarcity, claimed a group of planters in Bata in 1939. The "labour of the ganchos" had proved to be not as "fruitful as hoped": the ganchos, they said "forget their mission and use the opportunity to take a small holiday, coming back without braceros and with bad excuses." "Without a doubt the Africans employed for recruitment who are dispatched to do propaganda work, the ganchos, are not only inefficient, but as a rule they disappear with the money". ${ }^{111}$ Few familiar European figures remained after the Civil War, and the new "European, who is a stranger in a region and is trying to recruit [captar] braceros, is actually ignored!" The new wave of stranger-settlers in Río Muni were reduced to mere touts - "bargaining with the indigenas and telling them, 'Come to my factory I'll give you cognac'" in order to persuade them to sign contracts. ${ }^{112}$

As I have argued elsewhere, the ganchos had become totally unreliable, principally because they were not given enough money to relay as advances, because inflationary matrimonial expenses now far outpaced what could be gained through colonial wages. Even the most experienced reclutadores failed when they tried to restart what they had been forced to abandon, because the local economic terrain had been radically reconfigured. ${ }^{113}$ One example is Luis Pueyo, who, having "lived in Santa Isabel for some time”, went to Río Muni "in 1933 to dedicate himself exclusively to la recluta de braceros para la Isla de Fernando Poo, until this system was abolished". In 1935 he "became an independent contractor" in construction work and lead a "group of 60 of his own braceros". Pueyo and his crew were hired by the large firm ALENA (Compañía

111 GG (Suances) to SubGG (Cabrera), 21 November 1939, AGA, C-81/8195, E-2; Cámara Bata to SubGG (Cabrera), 11 November, 1939, AGA, C-81/8126, E-1.

112 SubGG (Barrueco) to GG (Alonso), 19 June 1942, AGA, C-81/8195, E-2.

113 Martino, "Nsoa ('dote'), dinero," 352-355. 
Naciónal de Colonización Africana), which at this point ran almost half of all coffee plantations and logging works in Río Muni, "to clear forest for their new coffee plantations in Monte Bata". Pueyo then recounts how in 1937 he was directly appointed as an agent "for la recluta" by a "representative of the Sindicato Maderero [logging lobby] in Ebebiyin and Mikomeseng", but that he "had to resign for his dealings were not producing any results." 114 As the great structuralist economist Román Perpiñá Grau noted during his fieldwork in the Río Muni of the early 1940s, la recluta had become unusually expensive and time-consuming, running to well over 1000 pesetas per recruit which included the advances and the "costs of displacement for 4 or 5 ganchos, trusted indígenas, and their stay in the forest during one month which might yield 10 braceros" - and "if we include their maintenance cost, as well as the truck and petrol, another 2500 pesetas is added to the costs of recruitment". 115

By 1939, the colonial employers in Río Muni started to "continuously ring the alarm in relation to the problema de braceros" - dangling in front of the occasionally hesitant colonial authorities the prospect of their cash crops "rotting" and the loss of precious foreign exchange revenues arising from any decline in the rate of logging, which was exported to Germany, to push through their proposal for new regimes of recruitment. In February 1939 the planters' lobby of Río Muni wrote to the Subgobernador that "the loss of great part of the harvest is immediately on the horizon," a cyclical horizon that rotated around the harvest time and the timetable of expiring contracts. They warned that the "employers will not be able to attend this urgent labour of harvesting coffee, nor will they be able to do all the preparatory work necessary for a successful harvest next year." 116 A sudden dip in availability would lead to a "destruction" of the potential wealth "so laboriously already created." The spectre that planters used to cow the administrators was that of a decaying "unharvested crop". As the head agronomist for the

114 SubGG (Calzada) to GG (Fontán), 1 October 1938, AGA, C-81/08195, E-2: "Reclutador Luis Pueyo Roldan". See also Juan Carlos Guerra Velasco and Henar Pascual RuizValdepeñas, "Civilizando la selva: capital, espacio y negocio forestal en la antigua Guinea continental española, c. 1926-1936', Historia Agraria 72 (2017): 135-166.

115 Perpiñá, De colonización, 365.

116 Cámara Bata (Ortiz) to SubGG (Cabrera), 9 February 1939, AGA, C-81/08126, E-1. 
Francoists, Jaime Nosti Nava says with a dose of pathologically naturalist poetry: "[A]n invasion of vines, reeds, and pests will mercilessly attack the forsaken plantations, fungi will start to eat away at the crops from their roots ... the forest drowns everything established by man and only vermin will reign as its sole proprietors". ${ }^{117}$ Haunted by their own macabre and unsustainable visions, the planters demanded a slash and burn recluta. A sarcastic characterization of a colonial planter from 1930 by a leading colonial ideologue, Juan Bravo, was revived without a hint of the original irony: the "slave trader with traces of the sociologist traverses the forest [and] exclaims: 'Oh, we should proclaim the social obligation to labour!' The planter on an exhausting tour [of Río Muni] remembers his cacao trees on the island of Fernando Poo and observes: Oh, you beautiful working machines, how well you would fit on my plantation!"118

A letter from the planters' lobby from April 1939 looked back at the "experience of the past 15 years of colonization" for "proof that everything that currently exists has not been obtained through the spontaneous cooperation of the indígenas, but through a directed cooperation, imposed in the name of civilization," which is to say through organized state violence directed at a specific "problema". The "government has acted whenever necessary in order to ameliorate our problems which afflict us continuously, namely the lack of brazos". Supplicating the Subgobernador, they gave the new Francoist colonial officials the basic outlines of their purpose: "The scarcity has only been relieved, time and time again, through the action of this Government, without which the indigenas would revert to their usual indifference". ${ }^{119}$ The silence or "indifference" to violence-infused colonial rule struck many observers as pathological. Some travellers misread this as a sign of "submissive" resignation, but those staying long enough in Spanish Guinea realized that this "resignation" was primarily due to the "dread of severe reprisals"

117 Jaime Nosti Nava, Agricultura de Guinea, promesa para España (Madrid: Instituto de Estudios Africanos, 1948), 32.

118 Juan Bravo Carbonell, "De la Guinea Española: el trabajo indígena," El Sol, 3 June, 1930.

119 Cámara Bata to SubGG (Calzada), 25 April 1939, AGA, C-81/8126, E-1. 
and "to the fact that indigenas were no longer allowed to carry weapons" after the full conquest of the late 1920s. ${ }^{120}$ During the years of the Spanish Civil War, the people of Río Muni were aware of the regime change. They had started the retreat from their subordinate position in the colonial labour economy by opening their own small coffee and cacao farms, a move the Republicans had started to enable, and were hoping that the Francoists would disappear as rapidly as they had appeared. The "indígenas are looking to see if the dark cloud passes, waiting to see if we will leave them alone", as the Subgobernador was still reporting in $1939 .{ }^{121}$

The Francoists became unusually responsive to the employers' myopic and wanting visions, and proceeded to set in motion grandiose schemes of unprecedented forms of forced labour. The new Gobernador Juan Fontán y Lobé (1937-1942) was quick to complain that "the planters put the problema at the feet of Government, they aren't doing much else, they are merely wanting to convert us into their reclutadores." Fontán maintained an ambivalent stance towards the praise of his despotic capacities: "[T] he planters lay out the problema de la falta de brazos at the feet of the organs of Government, as if it's the role of the Government to solve their problems. It is as if we grant them concessions in land and that automatically obliges us to supply them with labour power". ${ }^{122}$ This flattery was an old trick; planters had been pleading for these types of interventions since the 1890s. This letter to the colonial office from 1904 would not have been out of place in any other decade: "The labour question is perhaps the capital one for the future of the island [and we] turn to you, Mr. Minister, we implore you to ease our difficulties, alas, the lack of labour will cause the total ruin of the island". ${ }^{123}$ All twentieth-century regimes with the exception of the Republicans acceded the

120 Carles, Misioneros, negreros y esclavos, 33. For the context of the small wave of critical publications during the Republican period, see Mayca de Castro Rodríguez, “ ¿Anticolonialismo colonial? Crítica y blanquitud en la obra de Guillermo Cabanellas sobre la colonización de Guinea Ecuatorial," Journal of Spanish Cultural Studies 21, 2 (2020): 187-204.

121 SubGG (Cabrera) to GG (Fontán), 5 July 1939, AGA, C-81/8195, E-2.

122 GG (Fontán) to SubGG (Cabrera), 14 February 1939, AGA, C-81/8195, E-2; GG (Fontán) to SubGG (Cabrera), 15 February 1939, AGA, C-81/8126, E-1.

123 Hijos de Guill J. Huellin Sociedad Comandita, Barcelona to DGMC (Bosch), 1 August 1904, AGA, C-81/12894, E-271. 
planters' request by enforcing and intensifying prestación; but in the case of Río Muni no period was as intensive as the early Francoist years.

Francoist officers felt it was undignified to become a mere intermediary tool of the planters, and they framed their interventions as a provisional and "supplementary labour on our part, but the employers should continue, as they have done so far, the labor de captación" - the work of recruitment - "on their own accord." Fontán instructed his subordinates to try to "keep violence to a minimum" while setting out his vision for a prestación personal as the principal "arma", weapon, "that if ably handled by our district administrators can make the recalcitrant indigenas feel uncomfortable in their own village, so that they end up preferring to sign a contract". ${ }^{124}$ The district officers in Río Muni were to "create an environment that leads indígenas to contract themselves, for we will have to make it clear that he who does not want to work for himself, we will force to work for the collectivity." Already in the summer of 1939 this philosophy and reality was fully elaborated. Fontán's Subgobernador told him that "prestación is continuous. Once the indigena sees he must work without pay, it'll bring him, in the end, to the plantations. We should persist in the idea, that I think should persist forever, that prestación personal is foundational and fundamental to make potential workers contract themselves ... prestación for public works is only a means to this end." 125 Faced with overzealous administrators in the interior who had set off to inaugurate a very wide range of "public" works of one kind or another, primarily military infrastructure, with drafted prestación workers, Fontán advised them "to keep in mind that the timetable for completing construction work" is "secondary", as "our objective" was to "incline" or drive "the indigenas to work" in the contract economy. Over half of the 1,200 people subjected to prestación in the district of Bata in 1940 were put to work for more than six months. Fontán reduced prestación to a "reasonable amount of time", "let's say at least one day of work a week", and only applied to "the sixth part of

124 SubGG (Calzada) to GG (Fontán), 1 October 1938; GG (Fontán) to SubGG (Cabrera), 14 February 1939, AGA, C-81/8195, E-2.

125 SubGG (Cabrera) to GG (Fontán), 8 August 1939; SubGG (Cabrera), 25 December 1939, AGA, C-81/8195, E-2. 
the useful men of each village". The working day on prestación had also been extended and formalized under the Francoists, from 6am to 3pm, with Sunday off. ${ }^{126}$

In September 1939, the Subgobernador Augustin Cabrera, a former captain of an artillery unit during the Civil War, assessed the newly launched labour regime: "On the issue of braceros: It is not as tremendous a lion as people have been painting it. Things are going well. People are contracting themselves. Everything is going according to plan". Cabrera confirms that "decreeing prestación has been a much more effective way of bringing people to the plantation than all the work of propaganda by recruiters". ${ }^{127}$ The Francoists persisted and intensified. In 1942 a petition from the chiefs in Bata reads: "For five years now we indigenous people have been suffering daily under prestación personal, without pay whatsoever. We have not been able to attend to our own labours on our small coffee farms. Prestación causes great desertion from the villages. We are reduced to living melancholically in different parts of the country away from our families. All this misery is due to prestación. ... Our villages have been ruined and a great famine is imminent." The petition went on to submit a self-evident proposal to a new Governor that was lost on him, and they faced severe repression for making it: "The military should be barred from performing the activities of the administration, because not only does a military man not care to be just, he is also not bothered when being unjust. Everyone fears not being able to protest within their rights and reasons, losing by way of threats. ... [H]ere the Guardia Colonial is the enemy". ${ }^{128}$

The early Fang word for prestación is revealed in Dulu Bon be Afrikara, a still underappreciated piece of African history by the Bulu peasant intellectual, Ondua Engutu, written in the 1940s and first translated into a European language by the pioneering Guinean linguist, Julian Bibang. Speaking about the French regime of prestation in southern Cam-

126 GG (Fontán) to SubGG (Cabrera), 9 April 1940, AGA, C-81/8195, E-2.

127 SubGG (Cabrera) to GG (Suances), 12 September 1939, AGA, C-81/8195, E-2.

128 Jefes, Bata, to GG (Alonso), 12 June 1942, AGA, C-81/8182, E-6; Gonzalo Álvarez Chillida, "La protesta de los jefes en 1948: una tradición oral nacionalista en Guinea Ecuatorial,” Éndoxa: Series Filosóficas 37 (2016): 79-99. 
eroon after World War I, Engutu recollects the discussions held in the meetings around various Fang abas or "palaver houses" about the recent unfolding of colonial labour relations: "They even came up with a type of work, called sakasaane, that is after working you weren't paid." This line is accompanied in the more recent French translation of Dulu Bon be Afrikara by a footnote of the translator, Marie-Rose Abomo-Maurin, that says the word sakasaane is unknown to her, but "that one finds in this term, the second person plural of the present imperative." In Fang languages there is no actual word for "obey", there is only a dialogical relationship of obedience accorded and allowed in certain relationships. It is not that there was no imperative in Fang languages, i.e. a grammar of unconditional command: there is, but these were embedded and immanent in existing relationships. The despotic new language of the plural sakasaane required no mediations through everyday relationships or existing political structures, but entirely new relationships. ${ }^{129}$

In 1942, the Gobernador, Fontán, was promoted to director of the colonial office in Madrid. His replacement Mariano Alonso slowed the rhythm of prestación soon after receiving the petition of the Bata chiefs cited above. He insisted that "even though I know the lack of braceros is becoming more acute, it won't be me who cedes to the demands that the Cámara Agricola and the Sindicato Maderero are always making: compulsory lengthening of contracts and forced recluta in the villages" of Río Muni. Alonso continued the two-step approach outlined in the Fontán doctrine by keeping prestación for public works, with the aim of maintaining "voluntary" self-contracting. The state confined itself to acting as a middleman. By occupying this intermediary zone, the Francoist state claimed to replace the "disorder" of the recruitment that had reached its peak in the Republican period. However, like the Republican reformers, Fontán was naturally repelled by the previous status quo, the "recluta libre" which "had demoralized and denigrated the prestige of Europeans here". His long-term vision for the state to supersede the play of private interests and administer the recruitment and distribution of

129 Ondoua Engutu, La migración Fang: Dulu bon be Afri kara, trans. Julian Bibang Oyée (Malabo: Malamba, 1995); Marie-Rose Abomo-Maurin, Les pérégrinations des descendants d'Afri Kara (Paris: L'Harmattan, 2012), 185. 
labour could never be realized. The planters' lobby, as he says, "an entity led by private companies that have been granting themselves executive functions", was the overdetermining local power in the colony: it had managed to have at least one Francoist governor recalled to Spain for interfering in the labour question in the wrong way. ${ }^{130}$

The two-step principle of prestación was transformed in the later part of the three decades of the Francoist regime. Already the next Gobernador, Juan María Bonelli (1944-1949), was a partisan for what the Spanish liked to call the "external" and eventually the "Nigerian solution": "Does anyone think we can extract the fifty thousand braceros that the island needs to reach full production, plus several thousands more for the needs of the planters in Río Muni? Obviously not. As in times past, and present, we will need the braceros to come from other colonies". ${ }^{131}$ While prestación had led to a brief surge of braceros contracting themselves to the logging companies in Río Muni with a peak of 13,000 contracts signed in 1940, this figure fell to 7,500 braceros in Río Muni in 1943, with a significant number of workers, especially those in the forestry sector, being Fang from Gabon. However by 1943 two thirds of new contracts in Río Muni were already being made by Nigerian braceros. ${ }^{132}$ As the Curador in Santa Isabel told the logging lobby in 1940: "[I]f the current arrangement" with the Nigerian recruiters "continues (and we expect that it will) we [on the island] will be able to send [the employers in Río Muni] 400 to 500 braceros a month, and if this doesn't resolve the problema absolutely, well it's pretty damn close". ${ }^{133}$

A slightly bewildered visiting British diplomat, the Consul General at Brazzaville, on tour in Río Muni in the early 1950s observed that "in comparison with Fernando Po and the neighbouring French territories,

130 GG (Alonso) to SubGG (Perez Barrueco), 13 August 1942, AGA, C-81/8129, E-3; GG (Fontán) to SubGG (Cabrera), 15 February 1939, AGA, C-81/08126, E-1.

131 Juan Maria Bonelli Rubio, "Geografía económica de la Guinea Española," in España en Africa, ed. José Diaz de Villegas y Bustamente (Madrid: Instituto de Estudios Africanos, 1949), 193-204, 200. See my publications from 2016 and 2018 in the bibliography for a close study of the "Nigerian solution".

132 Curaduría, Bata, December 1944, AGA, C-81/08129, E-4: "Movimiento de braceros 1940-1944".

133 Curaduría (Carrillo) to GG (Fontán), 6 November 1940, AGA, C-81/08156, E-4; On Nigerian recruiters see my publications from 2016 and 2018 in the bibliography. 
it seems a poor and backward place. ... Apart from the Nigerians, who form a kind of native aristocracy, the Africans of the country looked depressed in comparison". ${ }^{134}$ His mention of Nigerian immigrants as an "aristocracy" is more than striking. There were up to 15,000 Nigerians under contract in Río Muni at this time, labouring under harsher conditions than in Fernando Po, because there was no British consular delegate in Bata to whom they could turn to raise their complaints of abuses. While Bonelli completed the shift to Nigerian labour, the Francoists had left Río Muni in a state of devastation after several decades of attempts to transform it into a labour reserve for the capitalist sector on the coast and on Fernando Po. There was a dogmatic perseverance with which forced labour was pursued by the Francoists - prestación was never abolished, it was gradually reformed to include remuneration and only formally reduced in the late 1950s, when the labour on the public works under prestación was overwhelmingly performed by unpaid prisoners. ${ }^{135}$ While in the 1930 s tribute labour was being abolished in other African colonies (except in the Portuguese territories, and only after World War II in the case of the French) its exceptional persistence in Spanish Guinea can be diagnosed as a type of collective punishment for what the colonial authorities would consider the Fang had brought onto themselves or provoked by refusing to continue to be subjected as braceros in the colonial economy: what Balandier called the "quest for autonomy". ${ }^{136}$ As Marx says in his chapter on "The Modern Theory of Colonisation" in relation to the designs intended to "manufacture wageworkers": "there the capitalist regime everywhere comes into collision with the resistance of the producer, who, as owner of his own conditions of labour, employs that labour to enrich himself, instead of the

134 TNA, FO 371/102621: "Tour by HM Consul General at Brazzaville, of French Cameroons, Fernando Po, Spanish Guinea, Nigeria and British Cameroons, April to May 1953".

135 This process of transformation needs much more research, there is abundant documentation in the archive, see AGA, C-81/13037, E-11; and the recent work by Celeste Muñoz Martínez, "La ley contra la costumbre. Segregación, asimilación jurídica y castigo en la Guinea Española bajo el franquismo (1936-1959)" (PhD Thesis, Universitat de Barcelona, 2020), 297-369.

136 Balandier, "The Colonial Situation," 51. 
capitalist." ${ }^{137}$ Even though he had the American settler colonies in mind, the specific colonial contradiction is the same, one between employers and an already somehow mobilized labour force, and not between the imperial state and its resident subjects.

\section{Conclusion: The History and Anthropology of Labour Recruitment}

The revival of labour history in a global comparative framework had opened vast research fields on neglected labour relations that did not neatly fall under the headings of either slave, forced or free labour. Of course, the regional historiographies had understood this need for a broader picture at the same time or earlier. For the plantation islands in the Gulf of Guinea William Clarence-Smith already noted that "every formula was tried. Slavery, indentured labor, forced labor, taxinduced migration, and free-wage labour", sometimes in no particular order. ${ }^{138}$ Larger ocean-centred historiographies were also building up these insights independently; so that, as Alessandro Stanziani says in relation to the nineteenth-century Indian Ocean, the total "variety of forms of debt bondage, indenture contracts, and other forms of bondage contracts, as well as genuine slavery" were present, at times almost simultaneously. ${ }^{139}$ But the "world-systemic" thesis, that colonialism and the development of global labour forces in capitalism produced a proliferation of unfree or semi-free labour is the foundational idea of global labour history as put forward by Marcel van der Linden and Shahid Amin

137 Marx, Capital, 767.

138 William G. Clarence-Smith, "Cocoa Plantations and Coerced Labor in the Gulf of Guinea, 1870-1914," in Breaking the Chains: Slavery, Bondage and Emancipation in Africa and Asia, ed. Martin A. Klein (Madison: University of Wisconsin Press, 1993), 150 $170,153$.

139 Alessandro Stanziani, Labour, Coercion, and Economic Growth in Eurasia, 17th-20th Centuries (Leiden: Brill, 2012), 1-28, 4; Gwyn Campbell, "Introduction: Slavery and other forms of Unfree Labour in the Indian Ocean World," Slavery \& Abolition 24, 2 (2003): ix-xxxii. A foundational comparative work is by Willemina Kloosterboer, Involuntary Labour since the Abolition of Slavery: A Survey of Compulsory Labour throughout the World (Leiden: Brill, 1960). 
in their special issue on Peripheral Labour: Studies in the History of Partial Proletarianization, and as recently powerfully restated in a special editorial note by Pepijn Brandon and Aditya Sarkar, the new editors of the International Review of Social History. ${ }^{140}$

The operations and influence of the figure of the recruiter has nevertheless been ubiquitously understated and even left out altogether in the new labour history. In a first instance, it seems obvious why recruiters are not one of its primary objects: they are categorically not labourers. The people who got lost in the study of free and forced labour markets have faded into a new background of "labour supply chains" or more powerful and determining structural forces, because it was assumed that in both cases they simply function as an automatic steppingstone without any power to affect or interfere in the organization of production. In the almost thousand-page volume Global Labour History: A State of the Art, the term "recruiter" does not even appear once - except when conflated with authoritarian "labor bosses" who were "recruiters and managers of labour" in China, and as state-run agencies for exporting domestic workers in Indonesia executing a management function. The most common type of recruiters in the colonial period were however not headmen, "boss-boys" or "gang masters" who supervised contracted labourers through their journey and at the worksite itself. They were rarely long-term employees. They worked on commission and were provisionally delegated agents, there to lay the groundwork, and only loosely affiliated to certain planters or employers. Similarly, the categorical matrices of the new labour history and types of labour relations produced for example by Jan and Leo Lucassen in Migration, Migration History, History, exclude the modalities of recruitment as an explicative and categorical axis, that would almost completely shape the experience

140 Shahid Amin and Marcel Van der Linden, eds., Peripheral Labour: Studies in the History of Partial Proletarianization (Cambridge: Cambridge University Press, 1997); Pepijn Brandon and Aditya Sarkar, "Labour History and the case against Colonialism," International Review of Social History 61 (2019): 1-37. For a more recent and more analytical synthesis see also Christian De Vito, Juliane Schiel, and Matthias van Rossum, "From Bondage to Precariousness? New perspectives on Labor and Social History," Journal of Social History 54, 2 (2020): 1-19; Sabine Damir-Geilsdorf et al., Bonded Labour: Global and Comparative Perspectives (Berlin: Transcript, 2016). 
and define the character of specific trajectories of labour migrants. ${ }^{141}$ While richly detailed, the conceptual retrogression that accompanied the rise of migration history at the expense of labour history, was noticeable. Only the developments of regional histories and the 2012 special issue put together by Ulbe Bosma, Elise van Nederveen Meerkerk and Aditya Sarkar, titled "Mediating labour" for the International Review of Social History, started reversing this tendency.

In the past decade there has been a noticeable uptick of studies of the broker in contemporary labour markets, often associated with the global industry of Gastarbeiter-like schemes or migrant smuggling during the Cold War and neoliberal eras, but there is surprisingly little historical interest or depth to these, because these studies come from sociologists and anthropologist who very rarely reach into the detail of the colonial period because of the problem of the layered and chaotic archive. ${ }^{142}$

141 Jan Lucassen, ed., Global Labour History: A State of the Art (Bern: Peter Lang, 2008), 381, 502; Jan Lucassen and Leo Lucassen, Migration, Migration History, History: Old Paradigms and New Perspectives (Bern: Peter Lang, 1997). Similarly, the role is not present in Marcel Van Der Linden and Magaly Rodriguez Garcia, eds., On Coerced Labor: Work and Compulsion After Chattel Slavery (Leiden: Brill, 2016), except in the interesting chapter by Justin F. Jackson on the American occupation of the Philippines, but in the figure of municipal official enforcers of the quasi-revived Spanish colonial practice of prestación personal. The labour code in Spanish Guinea adopted the language and parameters of the original decree, introducing it into the Philippines in 1859. "Real decreto extendiendo á todo el territorio de las Islas Filipinas el servicio de la prestación personal," Gaceta de Madrid, 162, 11 January 1859.

142 Johan Lindquist, Biao Xiang, and Brenda S.A. Yeoh, "Opening the Black Box of Migration: Brokers, the organization of transnational mobility and the changing Political Economy in Asia," Pacific Affairs 85, 1 (2012): 7-19. The only historical piece in this special issue is the extraordinary reflective essay by the late Adam McKeown, which is based on his extensive research into South Asian contract-based labour movements in the early colonial period, as well as Chinese indentured labour in Peru, Hawaii and in other emigration arrangements to Southeast Asia. McKeown is the most important and insightful author on contract labour and recruitment and a very welcome corrective to David Northup's classic Indentured Labour in the Age of Imperialism, which was conceptually fully immersed in the liberal commitments of an imperial self-modelling, and that book hast left an overall damaging effect for the historical study of contract labour and in particular recruitment. For contemporary African labour brokers, see the excellent studies by Maxim Bolt, "Waged Entrepreneurs, Policed Informality: Work, the regulation of space and the economy of the Zimbabwean-South African border," Africa 82, 1 (2012): 111-130; Maybritt Jill Alpes, "Why aspiring migrants trust migration brokers: The Moral Economy of departure in Anglophone Cameroon," Africa 87, 2 (2017): 304-321. 
There seems to be only enough historical interest to refute the false analogy of a continuity with the slave trade, and to attack the "securitized" state's vested interest in portraying brokers as "criminal and immoral as this allows them to deflect from their own responsibilities in creating structural conditions for the exploitation of migrant labour". ${ }^{143}$ Even in the clarifying theoretical works of Bruno Lamas or the genealogically orientated works of the social and political scientist Joel Quirk, who expertly follows the juridical and definitional turns of "modern slavery" starting from the crucial League of Nations period, there is little sense for how the different techniques and figures of colonial-era labour recruitment were the direct predecessors for the variety of types of "modern slavery". The foundational definition in the International Labour Organization's 1936 The Recruiting of Indigenous Workers Convention, as the orchestrating of an influx of those who did "not spontaneously offer their services at the place of employment" has never been taken as distinct from the other conventions on slavery and forced labour which have been the focus of "modern slavery" discourses. ${ }^{144}$

Even Marcel van der Linden's total refashioning of labour history in the tradition of a historical social science has had little practical application when trying to understand the unique dimension of recruitment as a particular mode of exchange in the labour market. He focuses on the recruiter occasionally and in an uncharacteristically unsystematic way, in the shape of supervisors of work-gangs, and when trying to determine the different principal upfront costs in different labour relations, which involve gathering "information about potential workers, and induce them to accept a labor relation", and finally as an employer's strategy when bypassing organized labour strikes and needing to "recruit" strike-

143 Bridget Anderson, "Where's the Harm in that? Immigration Enforcement, Trafficking, and the Protection of Migrants' Rights," American Behavioral Scientist 56, 9 (2012): 1241-57; Julia O'Connell Davidson, Modern Slavery: The Margins of Freedom (London: Palgrave Macmillan, 2015).

144 Bruno Lamas, When Looms Begin to Weave by Themselves: The Decomposition of Capitalism, Automation and the Problem of "Modern Slavery", Joseph C. Miller Memorial Lecture Series (Berlin: EB-Verlag, 2021); Joel Quirk, Anti-Slavery Project: From the Slave Trade to Human Trafficking. (Pittsburgh: University of Pennsylvania Press, 2014). Definition from The Recruiting of Indigenous Workers Convention, no. 50 (Geneva, International Labour Office, 1936), Article 2. 
breakers from the "reserve army" of labour. Only in his final and most empirical chapter of Workers of the World on "The Iatmul experience", detailing the recruiting boom in coastal Papua New Guinea between the German colonial period and the 1960s for the region's copra plantations, does he engage colonial-era sources that were overwhelmingly about recruitment to repeat some of the simplistic clichés of how "recruiters tried to lure men with Western steel tools" and to cite colonial-era ethnological tropes of Pacific subjects as undergoing permanent decline and being threatened with cultural disappearance due to the "massive temporary migration of young men to the plantations along the coast" created by the "'labor recruitment system". ${ }^{145}$

This lack of mutual empirical and conceptual communication between histories of labour mobilization and the classical social sciences is all the more surprising because some of the greatest ethnographies of economic and social anthropology in the twentieth century were precisely about labour migration and types of recruitment in colonial Melanesia, including works by Raymond Firth, Marilyn Strathern and Chris Gregory, as well as Adrian Graves' article "Truck and Gifts", one of the best article on recruiters from any region in the world. ${ }^{146}$ This early and continuous interest in twentieth-century anthropology for recruiters is possibly due to the fact that the areas where many early anthropologist first did fieldwork subsequently saw massive labour recruitment operations following the abolition of the slave trade. Indeed, Raymond Firth was one of the few pioneering anthropologists to systematically notice and account for these preceding waves of labour recruiters, recalling how he and his fieldwork assistants in Tikopia were plagued and hampered by rumours that they were labour recruiters. ${ }^{147}$ This generation of studies paved the

145 Marcel van der Linden, Workers of the World: Essays toward a Global Labor History (Leiden: Brill, 2008), 30, 66-67, 281.

146 Raymond Firth, Social Change in Tikopia: Re-study of a Polynesian community after a generation (New York: Macmillan, 1959), 34-40; Marilyn Strathern, No Money on Our Skins: Hagen migrants in Port Moresby (Canberra: Australian National University Canberra, 1975), 5-31; Chris Gregory, Gifts and Commodities (London: Academic Press, 1982), 112-155; Adrian Graves, "Truck and Gifts: Melanesian immigrants and the Trade Box System in Colonial Queensland," Past \& Present 101 (1983): 87-124.

147 Raymond Firth, Tikopia Ritual and Belief (London: Allen and Unwin, 1967), 150-151. 
way for the great achievements of world systems theory in the Pacific and historical economic anthropology, that precisely extended the focus to the relations of the "fourth world" with the other worlds: that is the areas "external" to the European capitalist world-economy and to its peripheries of production, such as the colonial or neo-colonial archipelagos of plantation islands. ${ }^{148}$ They overcame what Polanyi called the "abandonment" by political economics of the ultra-periphery deemed "irrelevant to an understanding of the problems of our age," even though the "differences existing between" this ultra-periphery and the capitalist core "have been vastly exaggerated, especially in the economic sphere". However the clues to how a global labour market was created outside of the paradigmatic case studies in early modern Europe, lay here. ${ }^{149}$

Polanyi's Great Transformation was subtitled, The Political and Economic Origins of Our Time. As the Spanish anthropologist Juan Aranzadi notes, the pre-colonial societies of Spanish Guinea had not been "state-ified" or "mercantilized" until their colonization, in contrast to large parts of West and Central Africa. My research on the formation of a colonial-era labour markets in the Gulf of Guinea has been preoccupied with positing and featuring recruiters as primary vectors of colonization across a variety of times and regions, within two different modalities I have elsewhere theorized as "touts" and "despots": one was based on independent and crisscrossing money-mediators or wage-advance dispensers and the other was driven by small incipient quasi-bureaucracies of viable punishment. Both arranged the labour supply for the cacao plantations in Fernando Po, at times simultaneously, but structurally oscillating and opposed. They emerged together and each rose in turn as a consequence of each other's failures and excesses, assembling and instituting the structural force and direct violence involved in the formation of colonial state power and wage labour markets. Yet I cannot

148 Nicholas Thomas, Entangled Objects: Exchange, Material Culture and Colonialism in the Pacific (London: Harvard University Press, 1991); Marshall Sahlins, "Cosmologies of Capitalism: The Trans-Pacific Sector of 'The World System'," in Culture/Power/History: A Reader in Contemporary Social Theory, eds. Nicholas B. Dirks, Sherry B. Ortner, and Geoff Eley (Princeton: Princeton University Press Princeton, 1994), 412-455.

149 Karl Polanyi, The Great Transformation: The Political and Economic Origins of Our Time (Boston: Beacon Press, 1957), 47. 
emphasize enough the importance of keeping distinct their strategies of labour recruitment.

Reclutadores found a quasi-autonomous and informal niche in empire. They ventured into the hinterlands as semi-familiar self-imposed sojourners and insinuated themselves into transforming local economies to relocate people into labour-hungry plantations. They carved out for themselves a slice of the profits gained through the labour market that they were themselves generating. Broker-mediated labour markets operated not only by charging commissions for creating a money-debt through institutionalized bondage, but by securing profits through "arbitrage", i.e. shifting the price towards the highest bidder. They operated as an inversion of the auctioneer, as they related to both employers and workers at a distance, unpredictably and usually illegally. As Joseph Miller notes, "slavers" were characterized by an explicit "marginality" which appeared in "context after context throughout world history, so that they could deal with sellers and buyers at arm's-length." 150 Through their own dispersal in a messily coordinated space, they could easily add their own complications and dimensions. In their own terms and with their own techniques they became the self-organized tools of commercial conquest and capitalist production. They did this with negotiation, usually involving the relaying of advance payment of wages and many other speculative exercises and deceptions, but unlike despots, without direct or even structural coercion.

150 Joseph C. Miller, The Problem of Slavery as History (New Haven: Yale University Press, 2012), 103, 107-111. 


\section{Acknowledgements:}

This text has benefited from the support of a Juan de la Cierva post-doctoral fellowship, financed by the Spanish State Research Agency, and is one of the results of the research project funded by the Spanish Ministry of Economy "Lo que sabemos, ignoramos, inventamos y deformamos acerca del pasado y el presente de Guinea Ecuatorial. Revisión crítica multidisciplinar y nuevas vías de investigación" (HAR2012-34599) lead by Juan Aranzadi (IP). I have benefited from various insightful readings and opportunities to discuss some of the findings and themes of the paper. I thank especially Christian De Vito, Michael Zeuske and Mariana Armond Dias Paes for the invitation and detailed discussion of my original, and shorter, Joseph C. Miller Memorial Lecture of the Bonn Center for Dependency and Slavery Studies (BCDSS), held on 8 June 2020. The paper has also benefited much from the workshop "Guinea Ecuatorial: La Huella Colonial", held at University of Barcelona in November 2020 and I wish to thank especially Gustau Nerín, Celeste Muñoz and Alba Valenciano. At an earlier stage I wish to thank Joseph Mangarella, Lotje de Vries and Andreas Mehler for the invitation to the excellent Point Sud and DFG workshop "Le long terme: Retracer les legs de la violence en Afrique équatoriale francophone" held in Libreville in November 2018 and the helpful discussions based on detailed readings by Enrique Okenve, Dimitri Ndombi, Lionel C. Ikogou-Renamy, and Florence Bernault. I would be remiss if I didn't thank the organizers and participants of the workshop where I first presented some of this material, including Andreas Eckert, Romain Tiquet, Cassandra Mark-Thiesen, Frederick Cooper, and Alexandre Käse at the workshop "The Creation and Evolution of Forced Labour in SubSaharan Africa under Colonial Rule" held in Ghana in 2014. Finally, my sincerest thank you to Tristan Oestermann, Peter Geschiere, and Gonzalo Álvarez Chillida for their readings and thoughts at the more complete stage of the paper. 


\section{Archives}

AGA: Archivo General de la Administración. Sección África. Alcalá de Henares, Spain.

ANC: Archives Nationales du Cameroun, Yaoundé, Cameroon.

ANG: Archives Nationales du Gabon, Libreville, Gabon.

BNE: Biblioteca Nacional de España, Madrid, Spain.

TNA: The National Archives of the UK, London, United Kingdom

\section{Abbreviations}

In footnotes: DGMC $=$ Colonial Office, Madrid (Sección Colonial del Ministerio de Estado, 1901-1925; Dirección General de Marruecos y Colonias, 1925-1931; Inspección General de Colonias, 1931-1936 [suppressed, 1934-1936]; Servicio Nacional de Marruecos y Colonias, 19381939; Dirección General de Marruecos y Colonias, 1939-1956); GG = Gobernador General de los Territorios Españoles del Golfo de Guinea, Santa Isabel; SubGG = Subgobernador General de la Guinea Continental, Bata; Curaduría = Labour Office, Santa Isabel (Curaduría Colonial, 1901-1941; Delegación de Trabajo, 1941-1968); Cámara = Agricultural Chamber of Commerce, Santa Isabel (Cámara Agrícola de Fernando Póo); Cámara Bata $=$ Agricultural and Logging Chamber of Commerce, Bata (Cámara Agricola y Forestal de la Guinea Continental). 


\section{Bibliography}

Abomo-Maurin, Marie-Rose. Les pérégrinations des descendants d'Afri Kara: Traduit de l'oeuvre Dulu bon b'Afrikara (écrit en boulou) de Ondoua Engutu. Paris: L'Harmattan, 2012.

Afigbo, Adiele E. The Abolition of the Slave Trade in Southeastern Nigeria, 1885-1950. Rochester: University Rochester Press, 2006.

Alexandre, Pierre, and Jacques Binet. Le groupe dit Pahouin: (Fang - Boulou - Beti). Paris: Presses universitaires de France, 1958.

Almonte, Enrique de. Someras notas para contribuir a la descripción física, geológica y agrológica de la zona noroeste de la isla de Fernando Poo y de la Guinea continental española. Madrid: Imprenta del Depósito de la Guerra, 1902.

Almonte, Enrique de. "Los naturales de la Guinea Española, considerados bajo el aspecto de su condicion de subditos españoles." Boletín de La Real Sociedad Geográfica LII, 4 (1910): 401-37.

Alpes, Maybritt Jill. "Why Aspiring Migrants Trust Migration Brokers: The Moral Economy of Departure in Anglophone Cameroon". Africa 87, 2 (2017): 304-21.

Álvarez Chillida, Gonzalo and Gustau Nerín. "Guinea Ecuatorial: el legado de la colonización española”. Ayer 109, 1 (2018): 13-32.

Álvarez Chillida, Gonzalo. "La protesta de los jefes en 1948: una tradición oral nacionalista en Guinea Ecuatorial". Éndoxa: Series Filosóficas 37 (2016): 79-99.

Álvarez Chillida, Gonzalo. "Claves de la historia colonial española de la Guinea Ecuatorial". In Guinea Ecuatorial (des)conocida: lo que sabemos, ignoramos, inventamos y deformamos acerca de su pasado y su presente, edited by Juan Aranzadi and Gonzalo Álvarez Chillida, 1:247-411. Madrid: UNED, 2020.

Amin, Samir. "Les effets structurels de l'intégration internationale des économies précapitalistes: une étude théorique du mécanisme qui a engendré les économies dites sous-développées". PhD Thesis, Université de Paris, 1957. 
Amin, Samir and Catherine Coquery-Vidrovitch. Histoire économique du Congo, 1880-1968: du Congo français à l'Union douanière et économique d'Afrique centrale. Paris: Anthropos, 1969.

Amin, Shahid and Marcel van der Linden, eds. 'Peripheral' Labour?: Studies in the History of Partial Proletarianization. Cambridge: Cambridge University Press, 1997.

Anderson, Bridget. "Where's the Harm in That? Immigration Enforcement, Trafficking, and the Protection of Migrants' Rights". American Behavioral Scientist 56, 9 (2012): 1241-57.

Arrighi, Giovanni. "Labour Supplies in Historical Perspective: A Study of the Proletarianization of the African Peasantry in Rhodesia". Journal of Development Studies 6, 3 (1970): 197-234.

Austin, Gareth and Stephen Broadberry. "Introduction: The Renaissance of African Economic History". The Economic History Review 67, 4 (2014): 893-906.

Azikiwe, Nnamdi. Liberia in World Politics. Westport, Conn.: Negro University Press, 1970.

Balandier, Georges. "Actualité du problème de la dot en Afrique Noire". Le Monde Non Chrétien 21, Janv.-Mars (1952): 36-47.

Balandier, Georges. "La situation coloniale: approche théorique". Cahiers Internationaux de Sociologie 11 (1951): 44-79.

Balandier, Georges. "The Colonial Situation: A Theoretical Approach". In Social Change: The Colonial Situation, edited by Immanuel Wallerstein, 34-61. New York: John Wiley \& Sons, 1966.

Balandier, Georges. The Sociology of Black Africa: Social Dynamics in Central Africa. London: Praeger Publishers, 1970.

Banaji, Jairus. Agrarian Change in Late Antiquity: Gold, Labour, and Aristocratic Dominance. Oxford: Oxford University Press, 2007.

Belinga, Samuel M. Eno, and Jane Guyer. "Wealth in People as Wealth in Knowledge: Accumulation and Composition in Equatorial Africa". The Journal of African History 36, 1 (1995): 91-120.

Bolt, Maxim. "Waged Entrepreneurs, Policed Informality: Work, the Regulation of Space and the Economy of the Zimbabwean-South African Border". Africa 82, 1 (2012): 111-30. 
Bonelli Rubio, Juan Maria. “Geografía económica de la Guinea Española”. In España en Africa, edited by José Diaz de Villegas y Bustamente, 193-204. Madrid: Instituto de Estudios Africanos, 1949.

Bosma, Ulbe, Elise van Nederveen Meerkerk, and Aditya Sarkar, eds. Mediating Labour: Worldwide Labour Intermediation in the Nineteenth and Twentieth Centuries. Cambridge: Cambridge University Press, 2012.

Brandon, Pepijn and Aditya Sarkar. "Labour History and the Case against Colonialism". International Review of Social History 64, 1 (2019): 73-109.

Campbell, Gwyn. "Introduction: Slavery and Other Forms of Unfree Labour in the Indian Ocean World". Slavery \& Abolition 24, 2 (2003): ix-xxxii.

Carles, Emilio. Misioneros, negreros y esclavos: notas de un viaje a Fernando Poo. Valencia: Cuadernos de Cultura, 1932.

Castro Rodríguez, Mayca de. “¿Anticolonialismo Colonial? Crítica y blanquitud en la obra de Guillermo Cabanellas sobre la colonización de Guinea Ecuatorial". Journal of Spanish Cultural Studies 21, 2 (2020): 187-204.

Clarence-Smith, William G. "Cocoa Plantations and Coerced Labor in the Gulf of Guinea, 1870-1914". In Breaking the Chains: Slavery, Bondage and Emancipation in Africa and Asia, edited by Martin A. Klein, 150-70. Madison: University of Wisconsin Press, 1993.

Cooper, Frederick. Decolonization and African Society: The Labor Question in French and British Africa. Cambridge: Cambridge University Press, 1996.

Coquery-Vidrovitch, Catherine. "The Colonial Economy of the Former French, Belgian and Portuguese Zones". In General History of Africa, Volume VII, Africa Under Colonial Domination 1880-1935, edited by A. Adu Boahen, 351-82. Paris: UNESCO, 1985.

Crush, Jonathan. Struggle for Swazi Labour, 1890-1920. McGill: Queen's Press, 1987.

Damir-Geilsdorf, Sabine, Ulrike Lindner, Gesine Müller, Oliver Tappe, and Michael Zeuske. Bonded Labour: Global and Comparative Perspectives. Berlin: transcript, 2016. 
De Vito, Christian, Juliane Schiel, and Matthias van Rossum. "From Bondage to Precariousness? New Perspectives on Labor and Social History". Journal of Social History 54, 2 (2020): 644-62.

Descola, Philippe. "Beyond Nature and Culture: Forms of Attachment". HAU: Journal of Ethnographic Theory 2, 1 (2012): 447-71.

Domenech, Jordi. "Legal Origin, Ideology, Coalition Formation, or Crisis? The Emergence of Labor Law in a Civil Law Country, Spain 1880-1936". Labor History 52, 1 (2011): 71-93.

Dupré, Georges, and Pierre-Philippe Rey. "Reflections on the Pertinence of a Theory of the History of Exchange". In The Articulation of Modes of Production, edited by Harold Wolpe, 171-208. London: Routledge, 1980.

Eckert, Andreas. "African Rural Entrepreneurs and Labor in the Cameroon Littoral". The Journal of African History 40, 1 (1999): 109-26. Engutu, Ondoua. La migración Fang: Dulu bon be Afri kara. Translated by Julian Bibang Oyée. Malabo: Malamba, 1995.

Fall, Babacar. "Le Travail Forcé En Afrique Occidentale Française (19001946)". Civilisations: Revue Internationale d'anthropologie et de Sciences Humaines 41 (1993): 329-36.

Feierman, Steven. "African Histories and the Dissolution of World History". In Africa and the Disciplines: The Contributions of Research in Africa to the Social Sciences and Humanities, edited by Robert Bates and Valentin Y. Mudimbe, 167-212. Chicago: University of Chicago Press, 1993.

Fernandez, James W. Bwiti: An Ethnography of the Religious Imagination in Africa. Princeton: Princeton University Press, 1982.

Fernández, Leonicio. Memorias de un viejo colonial y misionero sobre la Guinea Continental Española. Madrid: Revista 'El Misionero', 1950. Firth, Raymond. Social Change in Tikopia: Re-Study of a Polynesian Community after a Generation. New York: Macmillan, 1959.

Firth, Raymond. Tikopia Ritual and Belief. London: Allen and Unwin, 1967.

Fleitas Alonso, Carlos. Guinea, episodios de la vida colonial: relatos. Madrid: Agencia Española de Cooperación Internacional, 1989. 
Friedrich, Adolf. From the Congo to the Niger and the Nile: An Account of the German Central African Expedition of 1910-1911. Vol. 1. 2 vols. Philadelphia: J. Winston, 1914.

García Cantús, Dolores. “'Videant Consules': El Trabajo Forzado Bubi En La Colonia Española de Fernando Poo, 1891-1912”. In Between Three Continents: Rethinking Equatorial Guinea on the Fortieth Anniversary of Its Independence from Spain Hofstra University. New York, 2009.

Graves, Adrian. "Truck and Gifts: Melanesian Immigrants and the Trade

Box System in Colonial Queensland”. Past \& Present 101 (1983): 87-124.

Great Britain. Spanish Guinea. Historical Section of the Foreign Office.

No. 132. London: H.M. Stationery Office, 1920.

Gregory, Chris. Gifts and Commodities. London: Academic Press, 1982.

Guerra Velasco, Juan Carlos, and Henar Pascual Ruiz-Valdepeñas. “Civi-

lizando la selva: capital, espacio y negocio forestal en la antigua Guinea continental española, c. 1926-1936". Historia Agraria 72, Agosto (2017): 135-66.

Guthrie, Zachary Kagan. Bound for Work: Labor, Mobility, and Colonial Rule in Central Mozambique, 1940-1965. Charlottesville: University of Virginia Press, 2018.

Gutiérrez Sobral, Jose. "Guinea Española: la crisis de braceros”. Revista de Geografia Colonial y Mercantil 2 (1901): 12-15.

Harries, Patrick. Work, Culture, and Identity: Migrant Laborers in Mozambique and South Africa, c. 1860-1910. Portsmouth: Heinemann, 1993. Jackson, Justin F. “'A Military Necessity Which Must Be Pressed': The U.S. Army and Forced Road Labor in the Early American Colonial Philippines". In On Coerced Labor: Work and Compulsion After Chattel Slavery, edited by Marcel Van Der Linden and Magaly Rodriguez Garcia, 127-158. Leiden: Brill, 2016.

Jeeves, Alan. Migrant Labour in South Africa's Mining Economy: The Struggle for the Gold Mines' Labour Supply, 1890-1920. Kingston: Queen's University Press, 1985.

Jeeves, Alan, and Jonathan Crush, eds. White Farms, Black Labor: The State and Agrarian Change in Southern Africa, 1910-50. Portsmouth: Heinemann, 1997. 
Kloosterboer, Willemina. Involuntary Labour since the Abolition of Slavery: A Survey of Compulsory Labour throughout the World. Leiden: Brill, 1960.

Lamas, Bruno. When Looms Begin to Weave by Themselves: The Decomposition of Capitalism, Automation and the Problem of "Modern Slavery". Joseph C. Miller Memorial Lecture Series. Berlin: EB-Verlag, 2021. Lindquist, Johan, Biao Xiang, and Brenda S.A. Yeoh. "Opening the Black Box of Migration: Brokers, the Organization of Transnational Mobility and the Changing Political Economy in Asia". Pacific Affairs 85, 1 (2012): 7-19.

Llompart Aulet, Sebastian. Legislación del trabajo de los territorios españoles del Golfo de Guinea. Madrid: Dirección General de Marruecos y Colonias, 1946.

Llompart Aulet, Sebastian. "Anuario Estadistico de Los Territorios Españoles Del Golfo de Guinea”. Madrid: Dirección General de Marruecos y Colonias, 1945.

López Perea, Enrique. Estado actual de los territorios españoles de Guinea: conferencia dada en el Ateneo de San Fernando. San Fernando: Imp. Libreria de José M. Gay, 1905.

Lovejoy, Paul E. Transformations in Slavery: A History of Slavery in Africa. Cambridge: Cambridge University Press, 2011.

Lucassen, Jan, ed. Global Labour History: A State of the Art. Bern: Peter Lang, 2008.

Lucassen, Jan, and Leo Lucassen. Migration, Migration History, History: Old Paradigms and New Perspectives. Bern: Peter Lang, 1997.

Madrid, Francisco. La Guinea incógnita: vergüenza y escándalo colonial. Madrid: Editorial España, 1933.

Martino, Enrique. "Nsoa ('dote'), dinero, deuda y peonaje: cómo el parentesco fang tejió y destejió la economía colonial de la Guinea Española”. Éndoxa: Series Filosóficas 37 (2016): 337-61.

Martino, Enrique. "Panya: Economies of Deception and the Discontinuities of Indentured Labour Recruitment and the Slave Trade, Nigeria and Fernando Pó, 1890s-1940s". African Economic History 44 (2016): 91-129. 
Martino, Enrique. “Corrupción y contrabando: funcionarios españoles y traficantes nigerianos en la economía de Fernando Poo (19361968)". Ayer 109 (2018): 169-95.

Martino, Enrique. "Money, Indenture, and Neo-Slavery in the Spanish Gulf of Guinea, 1820s to 1890s". Comparativ 30, 5/6 (2020): 560580.

Marx, Karl. Capital. London: Lawrence and Wishart, 1974.

Mba, Leon. "Essai de droit coutumier Pahouin". Bulletin de La Société Des Recherches Congolaises 25, June (1938): 5-53.

Mbembe, Achille. La naissance du maquis dans le Sud-Cameroun, 19201960: histoire des usages de la raison en colonie. Paris: Karthala, 1996. McKeown, Adam M. Melancholy Order: Asian Migration and the Globalization of Borders. New York: Columbia University Press, 2013.

Meillassoux, Claude. Anthropologie économique des Gouro de Côte d'Ivoire: De l'économie de subsistance à l'agriculture commerciale. Paris: Éditions de l'École des hautes études en sciences sociales, 1964.

Meillassoux, Claude. Maidens, Meal, and Money: Capitalism and the Domestic Community. Cambridge: Cambridge University Press, 1981. Mendiola, Fernando. "The Role of Unfree Labour in Capitalist Development: Spain and Its Empire, Nineteenth to the Twenty-First Centuries". International Review of Social History 61, S24 (2016): 187-211. Miers, Suzanne, and Martin A. Klein, eds. Slavery and Colonial Rule in Africa. London: Routledge, 1999.

Miers, Suzanne, and Igor Kopytoff, eds. Slavery in Africa: Historical and Anthropological Perspectives. Madison: University of Wisconsin Press, 1979.

Miers, Suzanne, and Richard Roberts, eds. The End of Slavery in Africa. Madison: University of Wisconsin Press, 1988.

Miller, Joseph C. Way of Death: Merchant Capitalism and the Angolan Slave Trade, 1740-1830. Madison: University of Wisconsin Press, 1988.

Miller, Joseph C. The Problem of Slavery as History: A Global Approach. New Haven: Yale University Press, 2012.

Miranda Junco, Agustín. Leyes coloniales: legislación de los territorios españoles del Golfo de Guinea. Madrid: Imprenta Sucesores de Rivadeneyra, 1945. 
Muñoz Martínez, Celeste. "La ley contra la costumbre. Segregación, asimilación jurídica y castigo en la Guinea española bajo el franquismo (1936-1959)". PhD Thesis, Universitat de Barcelona, 2020. Mveng, Maurice. "Note sur emigration des Camerounais ä Fernando Po entre les deux guerres mondiales". Abbia 23 (1969): 34-43.

Nerín, Gustau. Corisco y el estuario del Muni: 1470-1931: del aislamiento a la globalización y de la globalización a la marginación. Paris: L'Harmattan, 2015.

Nerín, Gustau. La última selva de España: antropófagos, misioneros y guardias civiles: crónica de la conquista de los Fang de la Guinea Española, 1914-1930. Madrid: Los Libros de la Catarata, 2010.

Nerín, Gustau. "Y el cabo Nacarino tenía una guitarra... Investigando la conquista del Muni”. In Perspectivas antropológicas sobre Guinea Ecuatorial, edited by Juan Aranzadi Martínez and Paz Moreno Feliu, 189-201. Madrid: UNED, 2013.

Nietzsche, Friedrich. The Genealogy of Morals. New York: Random House, 1967.

N'Nah, Nicolas M. Domination coloniale au Gabon: Les combattants de la première heure. Paris: L'Harmattan, 1981.

Northrup, David. Trade Without Rulers: Pre-Colonial Economic Development in South-Eastern Nigeria. Oxford: Clarendon Press, 1978.

Northrup, David. Indentured Labor in the Age of Imperialism, 1834-1922. Cambridge: Cambridge University Press, 1995.

Nosti Nava, Jaime. Agricultura de Guinea, promesa para España. Dirección General de Marruecos y Colonias. Madrid: Instituto de Estudios Africanos, 1948.

O'Connell Davidson, Julia. Modern Slavery: The Margins of Freedom. London: Palgrave Macmillan UK, 2015.

Oestermann, Tristan. "Kautschuk und Arbeit in Kamerun: Soziale Mobilität, Zwang und Militanz unter Deutscher Kolonialherrschaft". PhD Thesis, Humboldt University of Berlin, 2020.

Oestermann, Tristan, and Peter Geschiere. "Coercion or Trade? Multiple Self-Realization during the Rubber Boom in German Kamerun (1899-1913)". In Beyond the Margins: The Political Economy of Life 
in Modern Africa, edited by Wale Adebanwi, 92-114. London: James Currey, 2017.

Okenve, Enrique. "They Never Finished Their Journey: The Territorial Limits of Fang Ethnicity in Equatorial Guinea, 1930-1963”. International Journal of African Historical Studies 47, 2 (2014): 259-85.

Okenve, Enrique. "Colonización, resistencia y transformación de la memoria histórica fang en Guinea Ecuatorial (1900-1948)", Ayer 109 (2018): 109-35.

Okenve, Enrique. "Equatorial Guinea 1927-1979: A New African Tradition". PhD Thesis, SOAS, 2007.

Okia, Opolot. Labor in Colonial Kenya after the Forced Labor Convention, 1930-1963. London: Palgrave Macmillan, 2019.

Onselen, Charles van. Chibaro: African Mine Labour in Southern Rhodesia, 1900-1933. London: Pluto Press, 1976.

Oyono Sa Abegue, Valentin. "L'évolution des structures productives et sociales de l'économie de la Guinée Equatoriale 1858-1968". Ph.D., Université de Lyon II, 1985.

Pélissier, René. Los territorios españoles de África. Madrid: Consejo Superior de Investigaciones Científicas, 1964.

Perpiñá Grau, Román. De colonización y economía en la Guinea española: investigación, sobre el terreno, de la estructura y sistema de colonización en la Guinea española, con referencia especial a lo económico, precedido de un estudio general de los territorios africanos. Barcelona: Tall. Ibero Americanos, 1945.

Polanyi, Karl. The Great Transformation: The Political and Economic Origins of Our Time. Boston: Beacon Press, 1957.

Pozanco, Ángel Miguel. Guinea mártir: narraciones, notas y comentarios de un condenado a muerte. Barcelona: Colección Actualidad, 1937.

Quirk, Joel. Anti-Slavery Project from the Slave Trade to Human Trafficking. Pittsburgh: Universtiy of Pennsylvania Press, 2014.

Ramos Izquierdo y Vivar, Luis, and Eduardo Navarro y Beltran del Rio. Descripción geográfica y gobierno, administración y colonización de las colonias españolas del golfo de Guinea. Madrid: Impr. de Felipe Peña Cruz, 1912. 
Rey, Pierre Philippe. Colonialisme, néo-colonialisme et transition au capitalisme; exemple de la Comilog au Congo-Brazzaville. Paris: F. Maspero, 1971.

Ritter, Karl. Neu-Kamerun, das von Frankreich an Deutschland im abkommen vom 4. november 1911 abgetretene gebiet. Beschrieben auf grund der bisher vorliegenden mitteilungen von dr. Karl Ritter. Jena: G. Fischer, 1912.

Rossi, Benedetta. "Dependence, Unfreedom and Slavery in Africa: Towards an Integrated Analysis". Africa 86, 3 (2016): 571-90.

Rüger, Adolf. "Die Entstehung und Lage der Arbeiterklasse unter dem deutschen Kolonialregime in Kamerun (1895-1905)". In Kamerun unter deutscher Kolonialherrschaft: Studien, edited by Helmuth Stoecker, 1:149-242. Berlin: Rütten \& Loening, 1960.

Sahlins, Marshall. "Cosmologies of Capitalism: The Trans-Pacific Sector of 'The World System.' " In Culture/Power/History: A Reader in Contemporary Social Theory, edited by Nicholas B. Dirks, Sherry B. Ortner, and Geoff Eley, 412-55. Princeton: Princeton University Press, 1994.

Sant i Gisbert, Jordi. "El comerç de cacau entre l'illa de Bioko i Barcelona. La Unión de Agricultores de la Guinea Española (1880-1941)”. Ph.D. Thesis, Universitat Pompeu Fabra, 2017.

Sanz Casas, Gonzal. 'Política colonial y organización del trabajo en la isla de Fernando Poo: 1880-1930'. PhD Thesis, Universidad de Barcelona, 1983.

Sanz Casas, Gonzal. "Los finqueros y el uso del trabajo forzado en la agricultura colonial de la isla de Fernando Poo". Arxiu d'Etnografia de Catalunya 3 (1984): 123-36.

Sautter, Gilles. "Les paysans noirs du Gabon septentrional. Essai sur le peuplement et l'habitat au Woleu-Ntem". Cahiers d'Outre-Mer 14 (1951): 119-59.

Sautter, Gilles. De l'Atlantique au flueve Congo. Paris: Mouton, 1966.

Seibert, Julia. In die globale Wirtschaft gezwungen: Arbeit und kolonialer Kapitalismus im Kongo (1885-1960). Frankfurt am Main: Campus Verlag, 2016. 
Servicio Geográfico del Ejército, España. "Mapa Del Golfo de Guinea”. 1963. Available at https://bibliotecadigital.aecid.es/bibliodig/es/ consulta/registro.do?id $=8202$

Stanziani, Alessandro. Labour, Coercion, and Economic Growth in Eurasia, 17th-20th Centuries. Leiden: Brill, 2012.

Strathern, Marilyn. No Money on Our Skins: Hagen Migrants in Port Moresby. Port Moresby and Canberra: Australian National University Canberra, 1975.

Sundiata, Ibrahim. Equatorial Guinea: Colonialism, State Terror, and the Search for Stability. Oxford: Westview Press, 1990.

Sundiata, Ibrahim. From Slaving to Neoslavery: The Bight of Biafra and Fernando Po in the Era of Abolition, 1827-1930. Wisconsin: University of Wisconsin Press, 1996.

Sundiata, Ibrahim. Brothers and Strangers: Black Zion, Black Slavery, 1914-1940. Durham: Duke University Press, 2004.

Tessmann, Günther. Die Pangwe: Völkerkundliche Monographie eines westafrikanischen Negerstammes. Vol. 2. 2 vols. Berlin: E. Wasmuth, 1913. Thomas, Nicholas. Entangled objects: exchange, material culture and colonialism in the pacific. London: Harvard, 1991.

Tiquet, Romain. Travail forcé et mobilisation de la main-d'œuvre au Sénégal: années 1920-1960. Rennes: Presses universitaires de Rennes, 2019.

Tonda, Joseph. Le souverain moderne: le corps du pouvoir en Afrique centrale (Congo, Gabon). Paris: Karthala, 2005.

Valero y Belenguer, Jose. "La Guinea Española: la isla de Fernando Póo". Boletín de la Real Sociedad Geográfica 32 (1892): 144-365.

Van der Linden, Marcel. Workers of the World: Essays Toward a Global Labor History. Leiden: Brill, 2008.

Van der Linden, Marcel, and Magaly Rodriguez Garcia, eds. On Coerced Labor: Work and Compulsion After Chattel Slavery. Leiden: Brill, 2016. Vansina, Jan. Paths in the Rainforests: Toward a History of Political Tradition in Equatorial Africa. Wisconsin: University of Wisconsin Press, 1990.

Weber, Max. "Commerce on the Stock and Commodity Exchanges [Der Börsenverkehr]". Theory and Society 29, 3 (2000): 339-71. 
Wirz, Albert. Vom Sklavenhandel zum kolonialen Handel: Wirtschaftsräume und Wirtschaftsformen in Kamerun vor 1914. Freiburg: Atlantis, 1972. Wolf, Eric. Europe and the People Without History. Berkeley: University of California Press, 1982.

Yglesias de La Riva, Ángel. Politica indígena en Guinea. Madrid: Instituto de Estudios Africanos, 1947.

Young, Crawford. The African Colonial State in Comparative Perspective. New Haven: Yale University Press, 1994. 

For further titles see: www.ebverlag.de

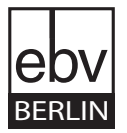

EBVERLAG DR. BRANDT

\section{WWW·EBVERLAG·DE}

Rainer Kuhl Tel.: 00493068977233

Jägerstraße 47 Fax:0049 3091607774

13595 Berlin E-Mail: post@ebverlag.de 
This study is, at once, a historical critique of neoclassical and Marxist economics of labour market formation, a critical history of the colonization of continental Equatorial Guinea by France, Germany and Spain, and a comparative inquiry of the labour recruiters who forged the gateways to expanding imperial peripheries of colonial production. A recruitment boom for the cacao plantations of the Spanish island of Fernando Po swept into Rio Muni and the Fang areas of southern Cameroon and northern Gabon during the first half of the twentieth century. By documenting the volatile phases as well as the recruitment techniques for this great boom and eventual bust, the author argues that recruiters have usually been empirically conflated or conceptually obviated even though they stood in sharp contrast to the slave trade or state-organized forced labour schemes. They were key informal vectors of commercial conquest across a variety of times and regions, and operated non-violently by way of persuasive and distorted communication and immanently through credit and money creation in the form of gifts and advance payments.

\section{THE AUTHOR}

Enrique Martino is a Juan de la Cierva postdoctoral fellow at the Complutense University of Madrid, and holds a PhD from the Institute of Asian and African Studies of Humboldt University, Berlin. He has been a postdoctoral fellow in Global History at the University of Freiburg (FRIAS) and at the Global Network for Global History project at the University of Göttingen. He has published in Comparativ, HAU, Ayer, Africa, African Economic History, History in Africa and the International Review of Social History and is completing two books, on labour and labour recruiters, and on money and monetary transformations in African and global history respectively. 